\title{
Swiss and Alpine geologists between two tectonic revolutions. Part 2: From drifting continents towards plate tectonics
}

\author{
Jean-Paul Schaer
}

Received: 30 January 2011/ Accepted: 24 September 2011/Published online: 26 November 2011

(C) Swiss Geological Society 2011

\begin{abstract}
Following the major contributions of Wegener and Argand (Part 1), it was the work of synthesis carried out by R. Staub that represented the major contribution Alpine geology made with respect to that heritage. The research work of young scientists (Gagnebin, Juvet, Wavre, Leuba) who had been influenced by Argand was of lesser importance. Ampferer's ground breaking contribution, coming along with illuminating graphic illustrations, was all but ignored. Although remaining fairly popular, the theory of continental drift found itself under the heavy fire of criticism from influential geologists in the USA and in Europe. In order to test the validity of the idea, C.E. Wegmann suggested linking geological field work with oceanographic research. He showed that the trajectories of drifting had to be conceived as following the small circles of the sphere. With regard to Alpine geologists of the time, they were renowned for the high quality of their geological mapping. This remained the very special activity in which they excelled, but they focused on topics that were becoming narrower and narrower, and increasingly specialised. The new avenues for research that Holmes and Hess opened up had but little impact on Alpine geologists. In fact, they apparently remained unaware of a note by Holmes written in German and published in a Swiss journal. On the eve of the Second World War, the meeting of the Geologische Vereinigung devoted to the origin of the Atlantic Ocean confirmed that continental drift was being seriously challenged, although a few papers pointed to new
\end{abstract}

Editorial handling: A.G. Milnes.

J.-P. Schaer $(\bowtie)$

Institute of Geology and Hydrogeology, University of Neuchâtel,

Rue Emile-Argand 11, 2009 Neuchâtel, Switzerland

e-mail: jean-paul.schaer@unine.ch developments, e.g. that in Iceland extensional tectonics had been active for the last 5,000 years. Most Alpine geologists were either highly critical of the theory of plate tectonic when it arrived or expressed serious reservations towards the idea. Of the exceptions, first Laubscher and then Bernoulli showed very clearly how important the new theory could be for understanding the evolution of Alpine orogeny. Continental drift and plate tectonics were very much the product of the creative imagination of human minds. Whereas Wegener used a broad range of confirmed results, plate tectonics sprang out of the new research being carried out in the domain of oceans. Graphic illustration was one of the favourite vehicles used to put across these new perspectives. Sometimes their impact remained alive long after their author had withdrawn his backing for the idea (as was the case for Argand's "embryonic tectonics"); sometimes, even in spite of their very high standard, they were just ignored (which was the case for Ampferer).

Keywords History of geological ideas .

Twentieth century - Alps · Atlantic $\cdot$ Continental drift . Plate tectonics

Résumé Après les contributions majeures de Wegener puis d'Argand, les synthèses de R. Staub représentent l'apport alpin majeur de cet héritage. Les travaux de jeunes chercheurs (Gagnebin, Juvet, Wavre, Leuba) gravitant autour d'Argand ont une portée mineure. L'apport novateur d'Ampferer, illustrés de dessins suggestifs préfigurant la tectonique des plaques, est largement ignoré. Gardant une certaine popularité, la théorie de la dérive des continents se trouve fortement critiquée aux USA et en Europe par des géologues influents. Pour en tester la validité, 
C.E. Wegmann, propose d'associés des travaux terrain, à des recherches en mer. Il montre que les trajectoires de dérives doivent être envisagées le long des petits cercles sphère. La cartographie de haute qualité des géologues alpins reste la voie privilégiée de leurs travaux, mais englobe des objets de plus en plus limités et spécialisés. Les ouvertures d'Holmes ou d'Hess n'ont que peu d'impact sur les géologues alpins. Une note du premier, rédigée en allemand et publiée dans une revue suisse, reste ignorée. A la veille de la guerre, la réunion de la Geologische Vereinigung consacrée à l'évolution de l'Atlantique confirme la contestation de la dérive des continents, bien qu'on signale, qu'en Islande, des distensions sont restées actives au cours des derniers 5'000 ans. La plupart des géologues alpins se montrent critique ou tout au moins réservé, lors de l'émergence de la tectonique des plaques. H. Laubscher, puis Bernoulli montrent au contraire tout l'intérêt que la nouvelle théorie apporte pour suivre l'évolution de l'orogenèse alpine. La dérive des continents et la tectonique des plaques ont été nourries par l'imagination. Alors que Wegener s'est servi d'un large éventail de résultats connus, la tectonique des plaques est née des investigation nouvelles du domaine océanique. L'illustration a été l'un des vecteurs privilégiés pour la présentation des nouvelles visions. Parfois leur influence a persisté au-delà du soutien de leur auteur (tectonique embryonnaire d'Argand); parfois, malgré leur qualité, elles furent ignorées (Ampferer).

\section{Introduction}

This article is the continuation and completion of the history of ideas and actions, which led to the concept of plate tectonics, as seen through the eyes of Swiss and Alpine geologists. In Part 1 of this history, ideas on the large-scale structure of the Earth and the hypothesis of continental drift were followed through the nineteenth century into the early decades of the twentieth (Schaer, 2010; see Appendix). At the beginning of the twentieth century, geologists believed that folded continental mountain chains like the Alps were due to horizontal compression, resulting from contractions of the Earth's crust as it cooled. In 1918, Albert Heim defended this point of view and illustrated it with a geological section across Switzerland (Heim, 1918). In 1915, however, and in short notes as early as 1912, the geophysicist and meteorologist Alfred Wegener in Die Entstehung der Kontinente und Ozeane (The Origin of Continents and Oceans) proposed that mountains were the result of collisions between light continents drifting and floating on denser material of the Earth's interior, which also formed the floors of the oceans (Wegener, 1912a, b, 1915, 1936). Before this, Ampferer (1906) had already proposed that mountain ranges were the result of active movements of material inside the Earth. Wegener used numerous morphological, palaeoecological, geological and gravimetric data to justify his hypothesis of drifting continents. He was innovative in his successful use of paleogeographic and paleoclimatologic reconstitutions. Although very popular, his concept only received reserved approval from the active scientific community. Most Alpine geologists found it too audacious and too far removed from the field data. In the first critical analysis written in French, Elie Gagnebin welcomed it as a working hypothesis, but was very reserved regarding the arguments of a geophysicist who, in his opinion, was not sufficiently versed in structural geology (Gagnebin, 1922). In contrast, Emile Argand integrated Wegener's (1915) theory into his conception of the evolution of the Alps already in a lecture given. At that time, for him, the Alpine orogeny had been the result of a permanent compression dominated by what he called embryonic tectonics, a concept which he illustrated so admirably that it had an incomparable and lasting success. However, he himself abandoned it in his major work, La Tectonique de l'Asie (The Tectonics of Asia), in favour of an evolution that first originated in an extension regime, finally leading to the splitting of the continental crust, with local emergence of basic rocks, constituting the bottom of new oceanic floors (Argand, 1924). He suggested that geosynclines were formed on the slope and at the foot of the continental margins by the large accumulation of sediments transported by submarine slumping. During the following compressive stage, intrusion of basic magma and slices of ocean floor were transported upwards between overlapping continental masses, forming extensive ophiolitic zones. Although admired for his enormous accomplishment, La Tectonique de l'Asie remained ignored for its most innovative propositions, which clearly foreshadowed plate tectonics. After this major work, Argand practically abandoned geology. His last publication, Guide géologique de la Suisse: la zone pennique (Geological Guide to Switzerland: the Pennine Zone, Argand, 1934), revived his argument of the early evolution of the geosyncline in a context of extension, followed by thrusts involving the ocean floor, but this concept, the precursor to plate tectonics, had no greater success than at its first appearance.

In spite of Argand's demise, some of his students at the University of Neuchâtel did carry these ideas out into the world in the 1920s and 1930s, and we pick up the story with these relatively unknown figures and the heritage which they carried forward (Chap. 2 in the following). Perhaps the most important bearer of his ideas, however, was Rudolf Staub, whose monograph Der Bau der Alpen (The Structure of the Alps) was partly written in Neuchâtel under Argand's guidance. Another person strongly 
influenced by Argand's ideas was André Amstutz, who introduced the term "subduction" into the geological vocabulary (Amstutz, 1951; White et al., 1970).

Following the Alpine connections through the period between the World Wars, influential carriers of Wegener's sweeping concept of continental drift and Argand's complementary ideas on collisional orogenesis become few and far between. As shown in Chap. 3, diverse opinions proliferate and many Alpine geologists prefer to study Alpine geology in ever greater detail without entering into debates about the larger picture or geotectonic consequences. C.E. Wegmann, a former student of Argand, became professor at Neuchâtel in 1940 and refused to teach the ideas of Wegener and Argand, maintaining that the kind of sterile and pointless debate which those ideas engendered should be avoided in favour of focussed research on solvable problems. Nevertheless, he proposed an ambitious multidisciplinary research project in the Arctic to test the drift hypothesis (which never became more than a proposal), and was one of the first to note that drift trajectories would have to be examined using the small circles of the sphere about any axis (Wegmann, 1948). A useful thermometer of the state of the drift debate at the beginning of World War Two is provided by the proceedings of the Atlantis conference of the Geologische Vereinigung, at Frankfurt am Main in 1939. Opinions were split into three: a third backed Wegener's propositions, a third were generally favourable but with important reservations, and a third were openly hostile to such ideas. There were, however, a few research contributions of note, such as an analysis of the fissure eruptions on Iceland suggesting extension at a rate of 2-6 $\mathrm{mm}$ per year over the last 5,000 years (Bernauer, 1939). The English-speaking world was also split at that time, with influential drifters such as $\mathrm{Du}$ Toit and Holmes on one side of the Atlantic and general rejection of the idea on the other, especially in USA.

In Chap. 4, the advent of plate tectonics in the late 1960s is viewed from the standpoint of Alpine geologists, mainly Swiss. The high quality cartography and geological mapping of Alpine geologists, which had brought so many outstanding results, remained their main method of investigation, and tended to become gradually more detailed and undertaken with a more and more specialized perspective. Most of them were persuaded that the Earth's evolution, its kinematics and dynamics, should be studied through a direct contact with rocks and that the sophisticated equipment of geophysics and oceanography were only of secondary importance. The main exception to this tendency was Hans Laubscher, who very early, followed by D. Bernoulli and others, applied the new concept to explain the small-scale and large-scale features of the Alpine orogen. Most Alpine geologists were more reticent and carefully chewed on the ideas, but slowly joined the revolution as different problems were addressed and found clarification. The process of slow awakening is best documented in relation to Rudolf Trümpy, the most eminent Alpine geologist of the time, an early "drifter" who gradually became a confirmed plate tectonician. As noted earlier (Schaer, 2010), the process can be followed precisely through a whole series of papers between 1970 and 1985 , as he slowly modified his convictions in the light of the developing theory and at the same time emphasizes the importance of continuing to collect field data and of keeping an open mind (Schmid, 2009).

The concepts of continental drift and plate tectonics were fed by the imagination of authors who knew how to use data selectively to develop systems with new integrative perspectives. Wegener used a large selection of geological results, most of them already known, mainly to illustrate crustal extension, the drifting apart of continents, with only a few comments on continental collision and Argand's results in later editions of his book. In contrast, plate tectonics was based on the acquisition and use of large body of completely new data from oceanography and geophysics. The authors who played a decisive role were able to combine the experience and data of both geophysical and geological domains. In all of the research on the Earth's dynamics, even more so than words alone, illustrations of conceptual models have had a great impact in presenting and supporting the new ideas. Sometimes the images were so strong that their influence persisted even longer than the support of the author who produced them (Argand and embryonic tectonics). Unfortunately, despite their evocative qualities, some were ignored (Ampferer).

\section{Argand's heritage}

In Neuchâtel as well as in Manchester (Marvin, 1985), the people who were going to commit themselves to the promotion of Wegener's and Argand's ideas were on the whole research scientists coming from the field of exact sciences (Schaer, 2003). In Neuchâtel, however, it seemed impossible that anybody should declare himself against that trend given the fact that Argand's commitment came to it so early in the day and because the aura surrounding his personality was so awesome. His influence seems to have been great, not only among his academic peers but also among students working in other fields of science. Among the latter one finds the mathematician Gustave Juvet.

\subsection{Gustave Juvet (1896-1936)}

After graduating in mathematics from Neuchâtel, Gustave Juvet (Fig. 1, Schaer, 2005), a friend of the psychologist Jean Piaget, moved to Paris to obtain his doctorat d'état 


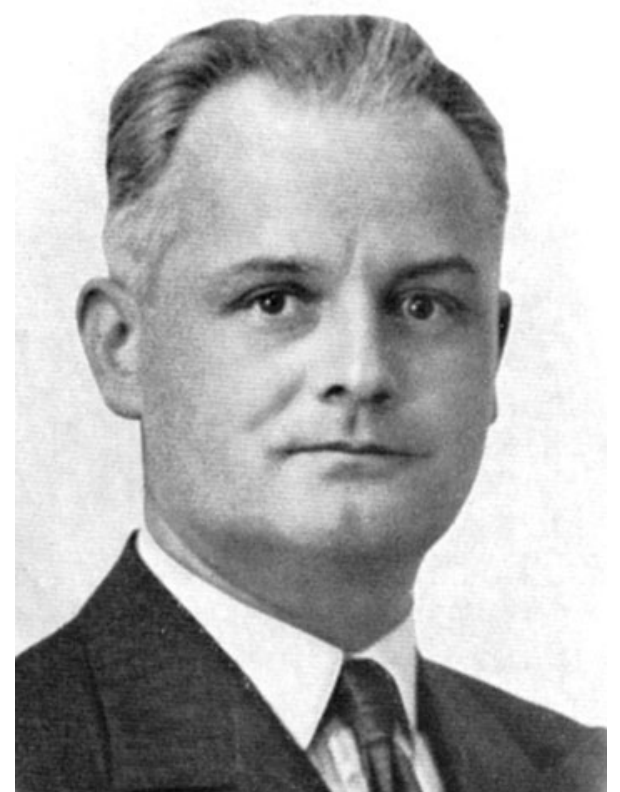

Fig. 1 Gustave Juvet (1896-1936)

from one of the universities in the French capital. Alongside the bookseller Blanchard he assumed the mantle of publisher and launched into the translation of a series of foreign scientific monographs dealing mainly with subjects in the field of exact sciences. Among the books published there were works by Weyl, Born, Sommerfeld, Jeans and Thomson. The first translation into French of Wegener's book under the title La Genèse des Continents et des Océans (Reichel, 1924) was number six of a series of 13 volumes, the only one in the field of natural sciences (Wegener, 1924). The translator, Manfred Reichel (Fig. 2), a student of German origin, was studying at the University of Neuchâtel after having followed classes at the Geneva School of Fine Arts. At the time, he was working on his doctoral thesis in biology. Argand appreciated the qualities that this artistic background brought along with it. He kept for himself sketches drawn by this student because they were endowed with a sense of geometry and an artistic flair close to his own ideals. In the foreword to the book, both the publisher and the translator thank Argand "for the interest he has shown towards their undertaking". In a letter to Gignoux, Argand believed that his own contribution had been of vital importance in throwing light on many a point in the original German text:

My feeling is that "Die Entstehung der Kontinente und Ozeane" is perfectly clear once put into French, and we have to express our warmest congratulations to Mr Manfred Reichel who has been the main instrument in reaching such clarity. $\mathrm{He}$ has been capable of grasping the finer nuances of our language

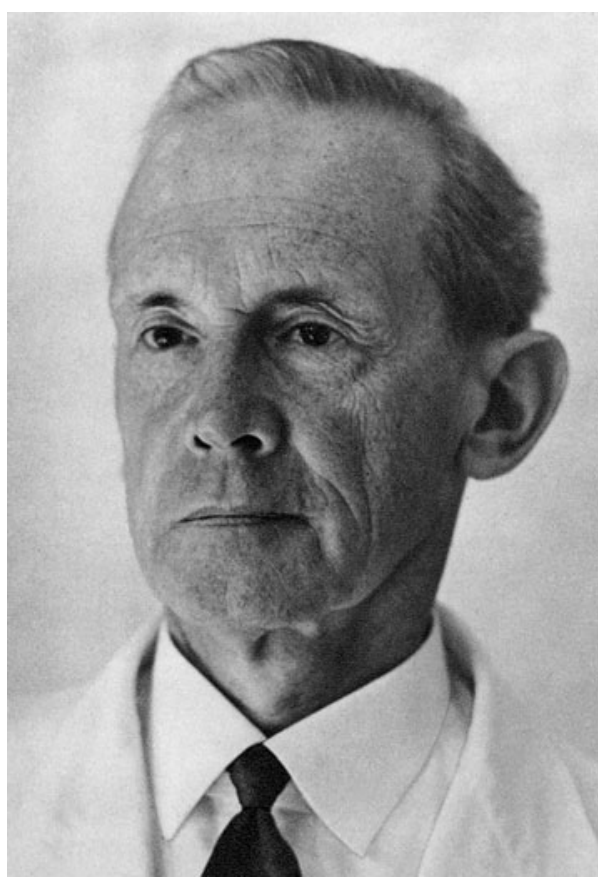

Fig. 2 Manfred Reichel (1896-1984)

and is almost equally at ease when dealing with the complex shades of meaning of the German tongue. Mr Reichel is my assistant and the work of translation has been carried out in my own laboratory. I went over a good deal of the translation in manuscript form with Mr Reichel, there were but very few pages we didn't examine together from three different angles: first that of the fundamental meaning of the text, then that of the various shades of meaning in the original German text, and finally from the angle of the syntax in French. (quoted in Schaer, 1991, p. 525).

In 1920, Juvet, who had not yet obtained his doctorate, was nonetheless asked by the University of Neuchâtel to stand in for one of the lecturers in astronomy and geodesy. The following year he was appointed as a lecturer in those fields, a part-time position he will hold until 1928, when he was appointed to the chair of vector calculus and analytical mechanics in Neuchâtel. His inaugural lecture in Lausanne underlined the fact that this young researcher was open to the modern developments taking place in the field of exact sciences. The lecture dealt with the application of Einstein's theories to the field of astronomy (Juvet, 1921). He offered an autographed version of this lecture to Argand: "To Professor Argand who is so well versed in geology, from the world of tiny little pebbles to that of gigantic nappes, my most delightful colleague and the most gentle of accomplices!” In Paris, a few years later, Juvet (1925) published an article on Wegener's theory and its implications. 
In spite of the magnificent dialectical aspect of the argument and the splendid way in which pieces of evidence fell into place, right from the start scientists seemed unconvinced, and if a few paleontologists and a few meteorologists rallied round Wegener's ideas, they were few and far between. The greatest number, and most specifically geologists, were extremely wary of the debate set in motion by Mr Wegener. Yet one geologist, one of the most illustrious, Mr Emile Argand, in a paper that will prove to be of crucial value and epoch making in the history of geology, has just shown that the theory of translations enables scientists to throw new light on the whole of the tectonics of Asia. (op. cit. p. 495).

Having examined the gravimetrical arguments concerning the collision between Europe and Africa, then that of India and Asia, Juvet came to the following conclusion:

Thus a new theory has come into being; let us offer congratulations and let us rejoice, for far from dismissing its forebears "to the world of purple shrouds in which dead gods are laid to rest" it has put to good use the viable arguments they included and incorporated them in a more harmonious pattern to new elements gained, thanks to the enduring patience and tenacity of explorers and scientists. What is more, it has found a solution to a few problems among the host of questions with which nature troubles the spirit of man, and it will solve a few others in the future. Under new approximations one finds the former ones; such is the way in which "the sound fabric of ideas, those serena templae erected in honour of human intelligence", survive. With Mr Argand, let us rest assured that what is of lasting value in them "will be grounded in the everlasting poetry of what is true, of that truth which is given to us piecemeal, in minute nuggets, which herald an order of the world whose majesty towers above time". (op. cit., p. 504).

Juvet's sudden death in 1936 put an end to what was a most promising career. In Switzerland, his influence on all questions concerning continental drift were to be further extended and bring forth new developments.

\subsection{Rolin Wavre (1896-1949)}

When Juvet got to Paris, Rolin Wavre (Fig. 3), who had been in the French capital since 1916 working on his own doctoral thesis in mathematics (Fehr, 1950), introduced him into Parisian scientific circles. On his return to Switzerland, Wavre was appointed to the University of Geneva and kept alive his marked interest in problems concerning geodesy and astronomy. Two papers, Berner (1925) and

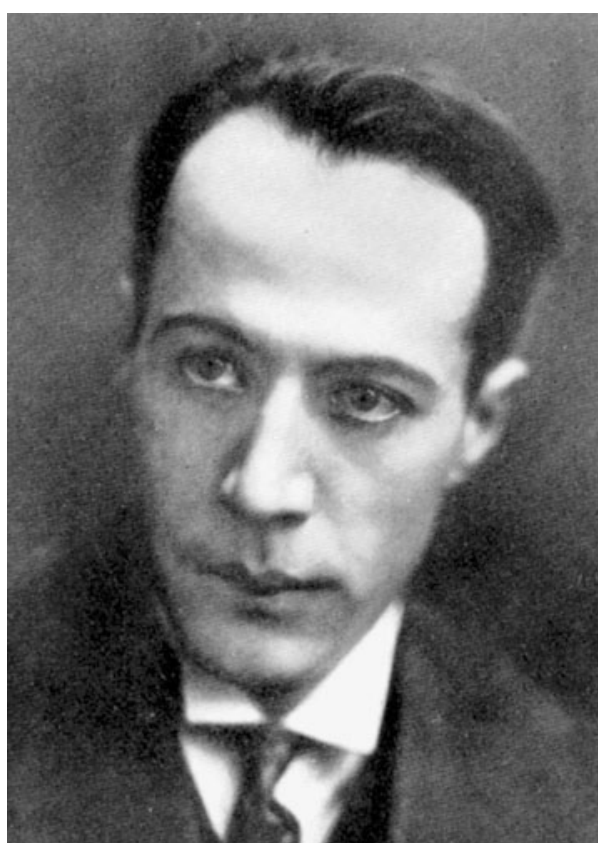

Fig. 3 Rolin Wavre (1896-1949)

Wavre (1925), came out of this interest: in them, the $\mathrm{PhD}$ student and his thesis director show that the forces set in motion by the rotation of the Earth, those which Wegener puts forward as providing the necessary drag for the drifting of continents towards the Equator, are extremely weak, and certainly not sufficient to bring about the formation of great mountain ranges. At the beginning of a subsequent paper, Wavre writes the following:

Wegener's hypothesis, which is certainly an endless source of questioning of our set ideas, as bold and creative as it may be, must be looked at without bias, from the standpoint of mechanics. It enables us to throw light on an array of phenomena in the most diverse of fields: palaeontology, climatology, tectonics, etc ..., which would otherwise seem utterly unaccountable. (Wavre, 1932, p. 2).

He finishes his paper by saying:

...the two forces thus brought to the fore ... are too weak to displace alone a floating body with respect to its own surroundings ... Then, the only assumption that can be made, would be that continents moved very little in relation to their direct surroundings and were dragged along with that very same environment by currents in the sima, of great amplitude and moving very slowly. This assumption could in any case better account for the preservation of the outlines of Africa and South America. (op. cit., p. 190).

A copy of the paper from which those lines are taken was sent to Argand with an inscription by the author. It is 
now in the geology library of University of Neuchâtel: it was still uncut and was thus never consulted by the person it was sent to.

In Geneva, a paper by Mercier (1933) on continental drift can also be seen as part of the same lineage, probably inspired by statements in the book of L. W. Collet (1935), who was at the time in charge of the teaching of geology at the university. This trend of thought, and the works it will bring forth, seems directly linked to the exchange of ideas that lived on among a small group of young researchers, all natives of Neuchâtel, who were under the influence of Argand and were particularly concerned about the development of modern scientific theories.

\subsection{John Leuba (1884-1952)}

Another important but little known personage, John Leuba (Fig. 4), is to be set in the context of exchanges between Neuchâtel and France, although he does not seem to have been in contact with the afore-mentioned group. The son of a pharmacist, and specialising in mycology, Leuba had first engaged in the study of natural sciences at the Academy in Neuchâtel, at the time the latter was being transformed into a university. Because of his interest in geology, he became Schardt's assistant at the new university and was later to marry his daughter. In 1916, he submitted a doctoral thesis dedicated to the study of batrachians from Colombia. At the time he was an assistant professor in the Histology and Embryology Department in the medical faculty at Geneva.

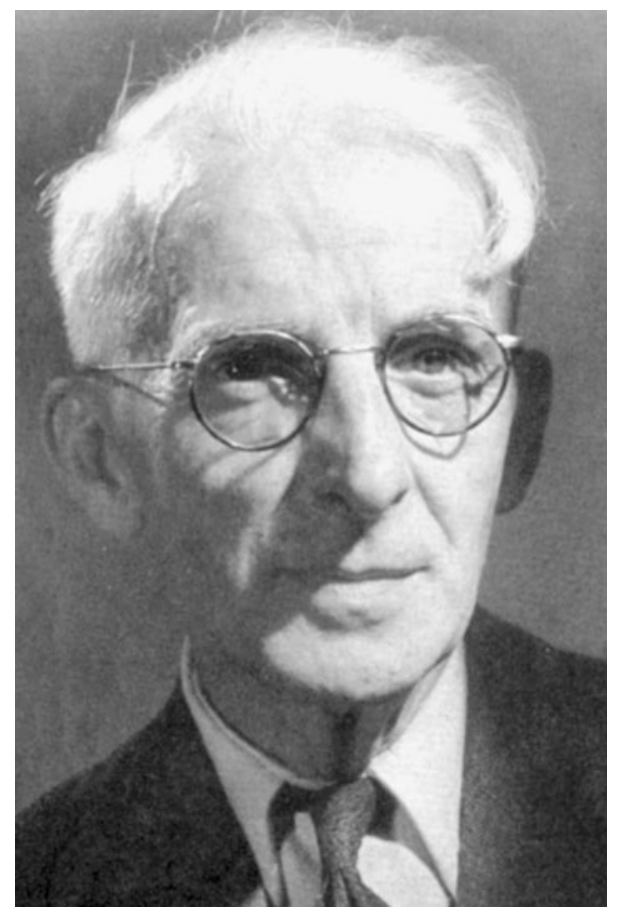

Fig. 4 John Leuba (1884-1952)
Once he had completed his thesis, he went over to France to work as a hospital volunteer, tending the wounded of the First World War. Once the war was over, he completed his medical studies in Geneva, then moved to Paris to work for the Armand Colin publishing house, where he brought out a textbook, Introduction à la Géologie (Leuba, 1925). The sixth and last printing of the book was in 1941, an indication of the success of this slender volume. Over the years, the author, by then deeply committed to the fields of medicine and psychoanalysis, will never change the text of the original edition. In his foreword to the book, he expresses his wish to give a vivid account of the current state of knowledge in geology, starting with contemporary phenomena (erosion and sedimentation) and transposing them to former periods in geological history.

Continental drift is introduced in the very first pages of the book, but it is in the core of the book that Wegener's ideas are expounded in detail, in the sections on general tectonics, and on the stratigraphy of the Carboniferous and Quaternary periods. At numerous places, Leuba underlines the importance of the ideas of his master, Schardt, and refers, for instance, to Schardt's research on the flow of water and its thermic role in the deep crust of the Earth, on the geometry of the folds of the Jura, and on the discovery of the various forms of Alpine overthrusts. However, it is to Argand's and Wegener's works that he constantly refers to when setting out the current ideas on the formation of the mountain ranges, ideas on which the whole dynamics of the Earth rest. Leuba acknowledges that the ideas put forward by these two authors are purely theoretical and must be carefully tested and sifted through in the light of pieces of evidence coming from the fields of geology, palaeontology and geophysics. At the same time, he underlines the beneficial aspects of those ideas for science in as much as they help to eradicate ideas that many people now deem obsolete. For instance, we read: "The latest pieces of research by Wegener and Argand have highlighted the fact that the impact of folding must be felt deep underground, in conformity with isostasy. The concept of geosynclines is thus seriously undermined, but even if it is doomed to fade away, it will have been a useful tool for the interpretation of facts that remain very real (Leuba, 1925, p. 77). In the USA, Field (1938) later came to the same conclusion (Oreskes, 1999, p. 254), but one will have to wait for several decades before seeing the community of geologists rally round those recommendations.

\subsection{Other carriers of Argand's ideas}

The group of young research scientists from Neuchâtel who tried to promote the ideas of both Wegener and Argand never made up a tightly knit group, and they never had the backing of their revered master. The local university was 
tiny in size: at the time there were barely two hundred students, taking all fields of study into account. This made it extremely difficult to recruit a great number of students of high calibre to the field of geology, which was considered to be very minor discipline. In addition, Argand seems to have been particularly keen on imposing his image of himself as the only outstanding scientist on the local scene. Through his theatrical poses he made everybody aware that he belonged to an altogether different world. In a letter from Argand to his friend P. Arbenz, dated January 10, 1916, he writes: “...if truth be told, students are much of a waste of time. When they are bright, they are ungrateful; when they are grateful, they are almost invariably rather stupid-the exceptions to this rule are few and far between." (Schaer, 2002, p. 276). Juvet, Reichel, Wavre and Leuba, and also Wegmann (see later), were all research scientists who later in life were to display great academic talent, and very often expressed the marks of their esteem to their master, Argand, and of the bond that they felt. Never was there the slightest hint of any encouragement emanating from him in the direction of his young admirers. The feeling of complicity and intimacy that Argand experienced in the presence of P.L. Borel, who was an Arts student and later to become a well-known writer and Argand's biographer, never found its like with the young students of science (Schaer, 1991).

In spite of this, and in spite of the circumstances which led Argand to gradually abandon geology after the publication of his main work (Schaer, 2010), during the later years of Argand's life and beyond, the interest for the theory of continental drift in Neuchâtel remained very much alive. Eduard Guyot (1934a, b, 1935), the Professor of Astronomy, who was the head of the local observatory, wrote two short papers on this subject. He analyzed the various data relevant to the measures of latitude and longitude from various geodesic stations in order to see whether the variations registered in time were compatible with the proposed drift of continental masses. Like other research scientists, he underlined the fact that the results obtained so far did not prove conclusive. He noted that in the case when movements seemed to exist, their magnitude was far below what Wegener had envisaged. In spite of those ambiguities, his opinion was that research had to be continued, paying special attention to increasing the accuracy of the measurements. Even if astronomy was not in a position to confirm continental drift, Guyot placed his whole trust in Wegener's ideas, convinced of the arguments indicating that continents which today are separated were once âtogether. In Neuchâtel high schools, as well as in other Swiss establishments of the same type, when the elements of geology were taught, which was not compulsory, the persons teaching the subject often repeated the arguments used by Argand and Staub, which had impressed them so much at the time they were students. It was thus that Wegener's ideas survived in Switzerland, as was the case in Britain (Marvin, 1985). It is well seen in a school textbook published much later in memory of Emile Argand (Dubois \& Portmann, 1955), called Histoire géologique de la Suisse. Also, in the very early post-war years, the small book by Gagnebin (1946), Histoire de la Terre et des êtres vivants, and its German translation by R. Trümpy, found a wide reading public. The book devotes a whole chapter to the theory of continental drift. Due to the acclaim the book received, it played an important role in keeping the idea alive in Switzerland, especially among the new generations interested in geology. It was in this way that the propositions of Wegener continued to be admired and propagated in the world at large.

In Switzerland, in spite of Wegener's and Argand's being kept very much alive, in the research community, the latter's line of thought did not lead to any further development that could, because of its inspiration and breadth of view, be considered as in direct line of descent. There is one exception to this assertion, and it is a major one. Given the very high calibre of his research on the Alps, and in view of his extraordinary intellectual inventiveness and great lyrical style, Rudolf Staub (1890-1961) showed himself in his early career a worthy disciple of the great pundit from Neuchâtel (Trümpy, 1991). The two men were almost of the same age, and for a few years they were close friends. The doctoral dissertation which Staub wrote under the supervision of Grubenmann, before he became friends with Argand, dealt mainly with petrographical problems. However, his first published paper showed that what we now call structural geology and tectonics was already at the very heart of his concerns. It was with that idea in mind that he first got in touch with Argand. According to him, it was in the course of a trip undertaken with the latter in the Graubünden that Argand suggested he should undertake a research project in the Eastern Alps that would complement the one he, Argand, had just carried out in the Western Alps. In order to do this, Staub spent several months at the institute in Neuchâtel. When this piece of research was published (Staub, 1924), the great friendship that had steadily built up between the two men just evaporated and was replaced by a deep rift. Argand had the impression that the book just made capital out of his own ideas and was forced to quickly publish a paper summarizing his opus magnum before it was completed (Argand, 1924), in order that his work took precedence over Staub's (see Schaer, 2010). He felt he had been wrong to introduce his ideas to the man who had come to him for guidance, before he himself had put them in written form. Later, some form of reconciliation took place and put an end to this violent clash (Trümpy, 1991). Argand, who was by then nearing the end of his seminal period in the domain of 
scientific ideas, never made any comment on his rival's subsequent publications. Staub, for his part, partially left behind Argand's ideas about continental mobility in favour of ideas focusing on the theme of fixity which were due to the influence of Kober and Stille (cf. Sengör \& Okurogullari, 1991, note 12, p. 247). According to Trümpy (1991), Staub, although less rigorous than Argand when it came to geometrical constructions, was a remarkable cartographer. He had a great capacity for synthesizing which was often backed by brilliant flashes of intuition. Over the course of the years he trained a host of young geologists at the Zürich Polytechnic (now the ETH Zürich). They seem to have been struck more by the inspired lectures he could deliver on the top of high mountains than by his theoretical approach (Trümpy, 1991). The critical glance that this new generation cast at a message that could seem, in their eyes, to be lacking in rigour, certainly contributed to the partial lack of trust they felt for the theory of continental drift, a theory whose impact, in any case, was by then on the wane in the whole of the scientific world.

Another heir to Argand's ideas was André Amstutz (1901-1981). Due to the various research projects he carried out in the Pennine Zone in the Valais and the Piedmont, as well as to the admiration he felt for Argand, Amstutz, the person who introduced in 1951 the term subduction into the vocabulary of geoscience (Amstutz, 1951, see White et al., 1970), had been strongly influenced by the great master. Following his period of training in Geneva, he carried out prospecting work in various parts of the world. This geologist-petrographer was to pursue a most successful industrial career, but he maintained a marked interest in Alpine geology and continued with his research in the root zone of Pennine nappes. However, as a researcher he was rather isolated and he was incapable of accepting any critical review of the assertions he was putting forward. As a result, his influence on the development of Alpine geology was practically non-existent, in spite of the originality of some of his work, and his particularly refined illustrations.

\section{Diverse opinions between the World Wars and beyond}

As has been noted in many works on the history of geology in the twentieth century, in the run up to the plate tectonic revolution, the period between the two World Wars seems to have been a time of stagnation. The debate around the concept of continental drift continued, with different intensity and with different emphasis in different countries, but it became less active and increasingly inconclusive. Intensive geological research on land in many parts of the world continued, also in the Alps, but it did not produce conclusive evidence, one way or the other, as few were relevant to assessing Wegener's or Argand's ideas. Knowledge of the oceans and its floor remained rudimentary and the new science of geophysics was engaged in its own controversies. Nevertheless, diverse strands of the arguments which would eventually be knotted together in the concept of plate tectonics were being followed, brooded over and digested. In this chapter, we follow the question of the drifting of continents further, through the inter-war period and into the post-war years.

\subsection{Neuchâtel in the post-Argand period}

From 1940, after having been active in Scandinavian countries and Greenland, it was Cäsar Eugen Wegmann (1896-1982) who found himself in charge of the teaching of geology at the small university of Neuchâtel. As one of Argand's former students he was reunited with several of his earlier fellow students. When it came to the problem of continental drift, he took them aback by his very reserved attitude and the guarded opinion he had formed through his subsequent contacts with a varied group of geosciencists. His turn of mind was rather conservative, and the experience he had derived from the various research projects he had been associated with in Scandinavia directed his own research towards the problems concerning the evolution of the deep crust of the Earth. At that time, it seemed that this type of research had little relevance to the question of continental mobility. As far as he was concerned, the work of Argand and even more so the ideas of Wegener should be excluded from any form of core teaching, even at university level. He considered that if undergraduates were introduced to these ideas without being in the position of grasping their finer shades of meaning, their implications and their limitations, the result would be that such ideas would very quickly become sterile and restricting. His attitude was very close to the one expressed by P. Termier (1926, p. 172) in his commentary to Wegener's propositions:

"It is in the very essence of such a theory to seem extremely convenient, which correspondingly brings along with it a major threat. The danger is that shallow minds will believe that riddles have found a solution, whereas they have just been brushed to the one side and replaced by another puzzle of much broader implications, and even more impenetrable."

Yet in some of his research work, Wegmann strove to make his position towards the problem of continental drift clearer (Wegmann, 1943a, b, 1948, 1950). His own wish was that the kind of sterile debates that seemed to be the rule when it came to discussing those ideas should be dropped in favour of research work focussing on targets 
that might bring clear-cut answers to some of the propositions. With that in view, he set out in various papers (e.g. Wegmann, 1943b, 1950) a research project in an Arctic region stretching from the north of Norway to the north of Canada by way of the northern tip of Greenland. He was far ahead of his time when he pointed out that the drift of continental masses on the surface of the globe must be examined through following the smaller circles of the sphere, whose axis of rotation could be at any angle in relation to the axis of rotation of the Earth. To try to shed light on the possible shift of the continents in those areas, he had his fellow astronomer Edmond Guyot draw up a special map using an oblique Mercator projection (Fig. 5), assuming that the masses displaced remained rigid, similar to the maps used later to show plate movements. For Wegmann, the research to be undertaken simply had to be multidisciplinary and major planning following the broad outline he sketched out. In order to get conclusive results, he maintained that research had to focus on the oceans, at that time still the great terra incognita. He displayed very clearly the keen interest he had in marine geology with regard to anything connected to morphology and sedimentology, as well as geophysics. Interesting though the research project may have been, it came to nothing. In any case, it would have been highly improbable that Wegmann himself could have led it. He was of a very anxious nature, and there was a deep sense of persecution was stamped on his personality. He would have found it extremely difficult to be involved in a common research project along with several other well-known scientists.

Later on, Wegmann tried to avoid referring to the problem of continental drift whenever possible. When he found himself cornered into doing so, his reservations were all the greater since the structural problems linked to the mobility of deep orogenic zones which he had investigated in Scandinavian countries and in Greenland were for him more fundamental, and more accessible, than the problem of continental drift. In the confined world of the small university town of Neuchâtel, the misgivings he expressed towards what he considered to be the myth of continental drift had but very little impact on the prestige bestowed upon concept, and with such panache, by his illustrious predecessor.

\subsection{Other Swiss connections}

Léon-William Collet (1880-1957), who since 1918 had been in charge of the teaching of geology at the University

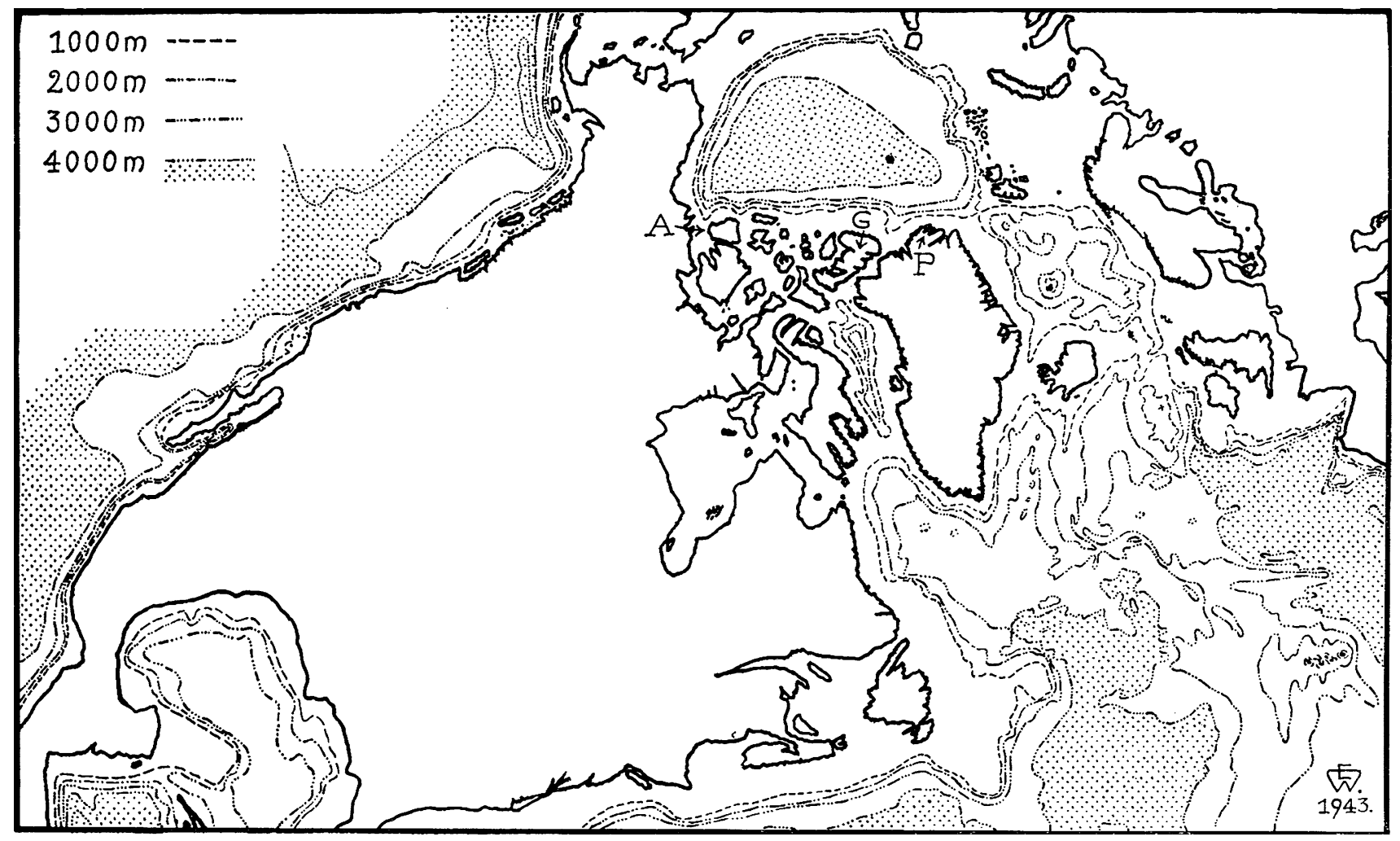

Fig. 5 Map of Nordic countries in an oblique Mercator projection showing a great circle running from northern Norway, passing $\mathrm{W}$ of Spitzbergen and $\mathrm{N}$ of Greenland, to the Amundsen Strait from a document prepared for the analysis of continental displacements along the De Geer Line (Wegmann, 1943b) 
of Geneva, can be regarded as a great advocate in the defence of Wegener's and Argand's research work (Paréjas, 1957). This specialist on the Helvetic nappes between the Arve and the Rhone rivers in the Central Alps, and the Aar massif with its infolded autochthonous cover (EigerJungfrau line), was a great mountain climber. He played a major role, towering way above any of his academic peers, when it came to publicising what was known of Alpine and Swiss geology in English-speaking countries. His main contribution was his well known book, The Structure of the Alps (Collet, 1935), which became a reference textbook, not only in Great Britain but in Switzerland as well. The lectures that this great scholar delivered in England, and his teaching of Alpine geology at Harvard University over the course of three winter semesters (1927-1929), did much for the dissemination of knowledge of the Alps.

What made Collet's The Structure of the Alps so special was the set of very high quality graphic illustrations which gave the book a special status. There were many crosssections that underlined very clearly the majesty of the Alps as well as the complexity of its structures. Beyond the frontal zones of the Northern Alps in which the author used data gathered in the course of his own research work, the illustrations that came along with Collet's text were the work of Staub and Argand. Collet, who had very little inclination towards theoretical speculation, devoted a little over one page to Wegener, trying to set out clearly the factual elements of his theory. In this context, he mentioned the commentaries of Argand on the large masses of mafic rock that occur under the Dent Blanche thrust, which Argand interpreted as intrusions associated with the emplacement of the nappe.

The intrusion of basic magma in the dislocation upon which the Dent Blanche Nappe advanced is also a matter of fact. I have myself seen the evidence in the field, guided by my friend Argand, and have shown it to many English geologists. ...I must state explicitly that all these results have been obtained independently of Wegener's hypothesis. That is why I think that they are a great support to Wegener's theory. ...As shown by Lord Rayleigh, many facts make it necessary to abandon Kelvin's classical theory of the cooling of the Earth. The work done by Prof. Joly in this direction is of great value, and it will soon be impossible to resist Wegener's attractive ideas. (Collet, 1935, pp. 26-27).

In that context, as was the case for many research scientists, Collet was not aware that what for him was $a$ fact, was nothing more than one of Argand's interpretations, which would ultimately be questioned.

In 1930, in the context of an academic exchange, the University of Basel called upon Arthur Holmes, who was then professor at Durham University, to deliver a series of lectures about geology and radioactivity (Holmes 1928a). The lecture notes were later translated into German by Professors Reinhardt and Preiswerk and subsequently published under the title Radioaktivität und Geologie (Holmes, 1930). Beyond the geochemical and geophysical data, this work also considered the origin of convection currents and the mechanism of continental drift, leading to phenomena that sometimes seemed to come very close to what Argand had proposed, although neither Argand's or Wegener's names are mentioned. This publication, with its suggestive figures going back to previous research work (Fig. 6) was not to have any impact at all among Alpine geologists.

During the inter-war period, in Neuchâtel as well as in the rest of Switzerland, the leading figures who had any publications to their names were still strong supporters of the theory of continental drift. At the time, there were certainly people who were sceptical of the whole thing, but apart from Schardt (1928) they did not publish anything on the matter and it is difficult to assess the weight of the support such a position had. Nevertheless, during the course of the 1940s and 1950s, the public at large remained deeply marked by Wegener's theory, whose influence was still great. This was particularly the case among the young people who showed an interest in geology. In Switzerland, the stamp and influence of Wegener was kept alive through the positive impact he had had on the people who were teaching in secondary schools and universities, like Gagnebin in Lausanne and Collet in Geneva. The admiration they had felt for him lived on. Ill-informed of the reservations expressed by many research scientists working in the field, the young generation proved particularly receptive to the theme of continental mobility, and in their eyes that the theory of plate tectonics promoted this theme was one of its main attractions. The situation seems to have been quite different in France where textbooks, with the exception of the one by Leuba, made reference to Wegener's theory as some kind of oddity, perhaps a very clever oddity, but still very much of a quirky idea (Ray, 2004). With respect to Argand, although he remained much admired, the new generations launching into new research and mapping in mountainous areas found that his message did not provide the auspicious background on which they could rely. In his La Tectonique de l'Asie, Argand had stretched this line of research to its very limits. The direction taken by Staub had not brought any promising new openings. People sought new inroads in other directions, in other disciplines. Those innovating influences which looked beyond the boundaries of regional geology, which still had a dominant position, had to wait for half a century before the deep structure of the Alpine range was elucidated, by a combination of a deepened understanding 

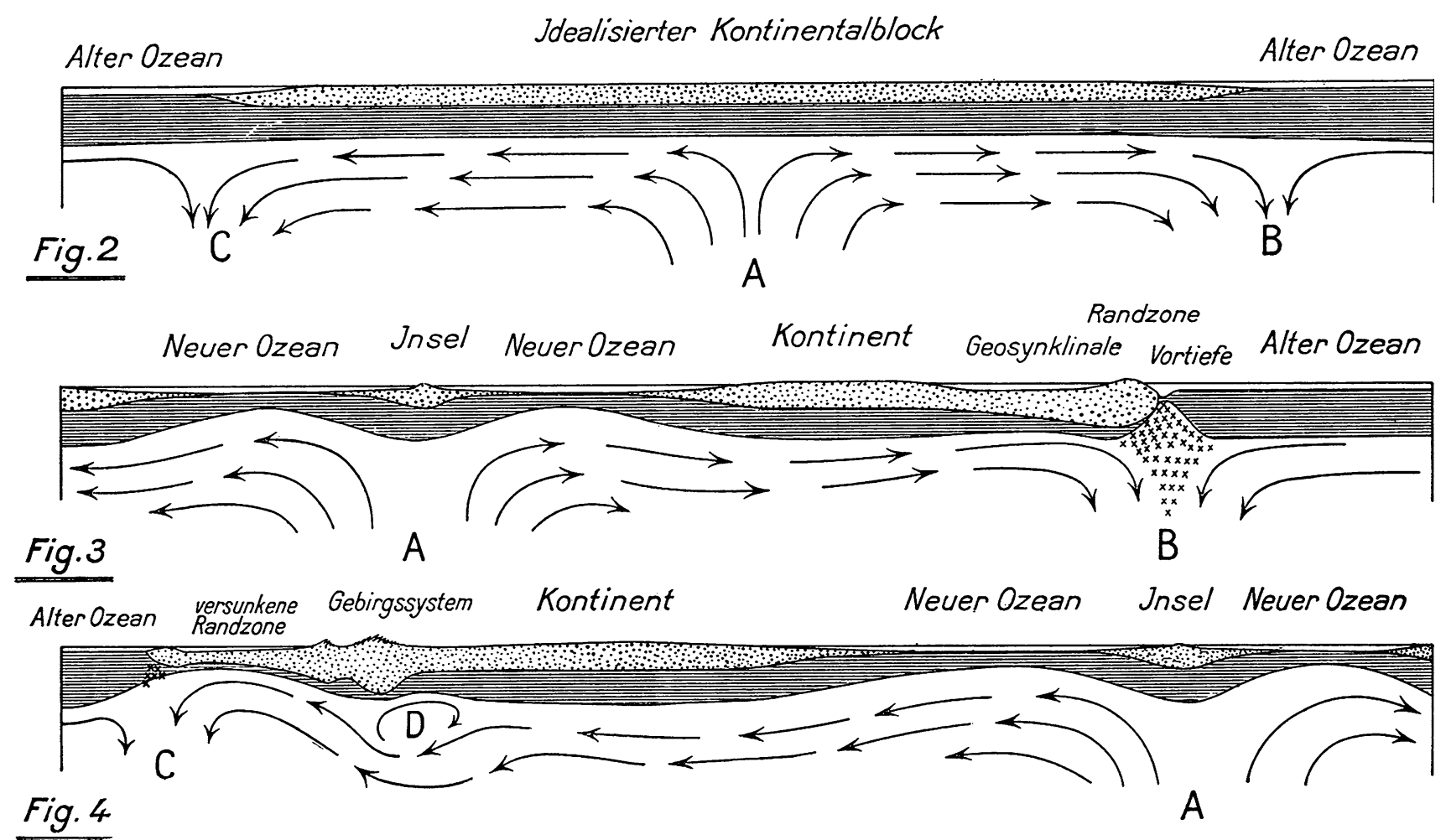

Fig. 6 Convection currents presented by Arthur Holmes in the article published in German in Basel (Holmes, 1930). Fig. 2: situation of a continent before continental drift-below an idealised continental block (lightly striped, above $A$ ), presence of convection currents inside the Earth, rising at $A$ and plunging downwards at $B$ and $C$. Fig. 3: pulling apart of the continent-the splitting of the

of tectonic processes based on surface geological mapping and the application of deep seismic sounding, a partnership between geology and geophysics (Pfiffner, Lehner, Heitzmann, Muller, \& Steck, 1997). Strangely enough, it was then that Argand's genius really became apparent-compare the cross-section of Central Alps in Argand (1924) Fig. 5 in Schaer (2010) —with the geological interpretations of the deep seismic profiles in Pfiffner et al. (1997).

\subsection{Ampferer on continental mobility and drift mechanisms}

The early work of Otto Ampferer on continental mobility, a subject that he continued to propagate throughout his life, presaged that of Wegener (Schaer, 2010, see also von Klebelsberg, 1947). In his article on the tectonics of the Alps (Ampferer (1924b), he made very clear his commitment to Wegener's ideas, but he found fault with the proposed mechanisms. A year later, he made his position on the subject is even clearer (Ampferer, 1925). He illustrated his article with very simple diagrams, which were not in the least dazzling but indeed remarkably pertinent (Fig. 7). Nowadays, his commentaries are still relevant and continental block leads to the formation of oceans and islands (above $A$ ), whilst at $B$, the enriched Sial forms a rising border zone in front of a foredeep-trench with the formation of a geosyncline behind. Fig. 4: another situation, above the descending current at $C$-a turbulence develops at $D$ due to heat transport from $A$ to $C$, causing mountain building and a submerged marginal zone towards the old ocean

some of his illustrations can be perceived as a clear pointer in the direction of plate tectonics. They seemed too simple and were too far in advance of their time, and as a consequence nobody paid any attention to them, neither at the time of their publication nor afterwards. The hypsometric curve of the earth he (Fig. 7a, lower graph) was several steps ahead of the one put forward by Wegener (Fig. 7a, middle graph), in as much as he clearly brought out the association between the deep oceanic trenches and the active orogenic zones. He also suggested, as one of several mechanisms, that new oceanic domains may be created by the repeated supply of magma, filling the space as the continents moved apart (Fig. 7b, lower sketch). His diagram suggests analogies to modern magnetic anomaly maps astride mid-ocean ridges. For Ampferer, the westward drift of the American continental raft, floating on the sima as Wegener proposed, should, on the Pacific side, show a natural levee formed of the accumulation of oceanic material, as Argand had suggested, whereas the Atlantic side should show a depressed zone. In his opinion, the absence of such structures underlined the fact that the external forces causing such a drift were very weak. However, he pointed out, those objections no longer stood 
(a)
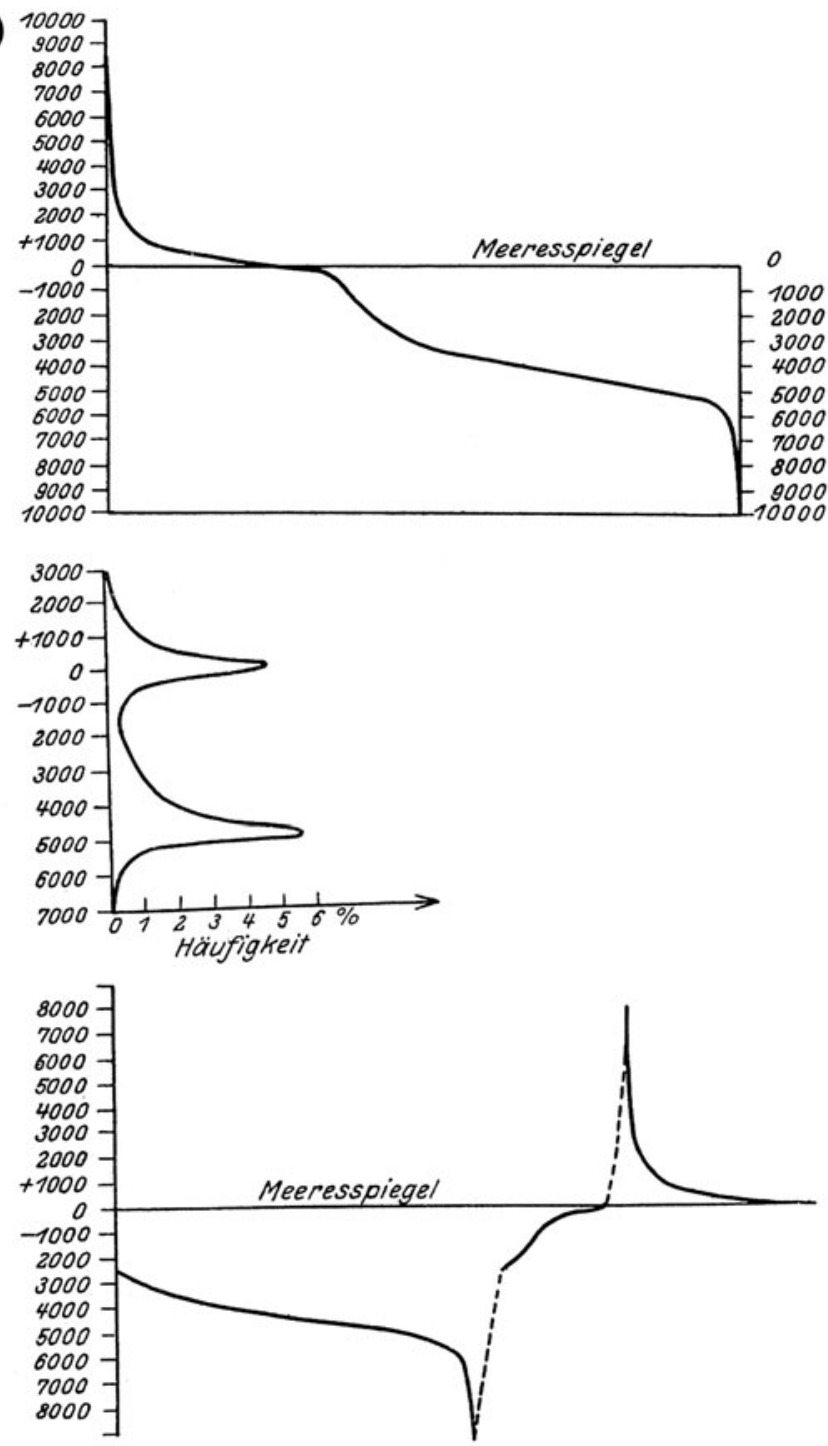

Darstellungen der hypsometrischen Kurve der Erdoberfläche. Oben nach KRƯMMEL, in der Mitte nach WEGENER, unten in natürlicher Anordnung der Hauptelemente.

Fig. 7 Illustrations from Ampferer (1925) in support his ideas on continental drift and the role of convection currents. a Hypsometric curves of the Earth's surface comparing different authors: above, Krümmel, in the middle, Wegener, and below, Ampferer. b The different geometrical and geological possibilities of accommodating

the moment one assumed that the shifts on the crust of the Earth were induced by movements of material coming up from the depths of the Earth, which as they came up beneath continents, were directed on a course tangential to the surface of the Earth. In such a scheme, the trenches located, for instance, along the west coast of the South American continent would serve as zones down which matter was pulled in order to compensate for the accretion of matter moving up. Ampferer even went as far as (b) Einbiegung
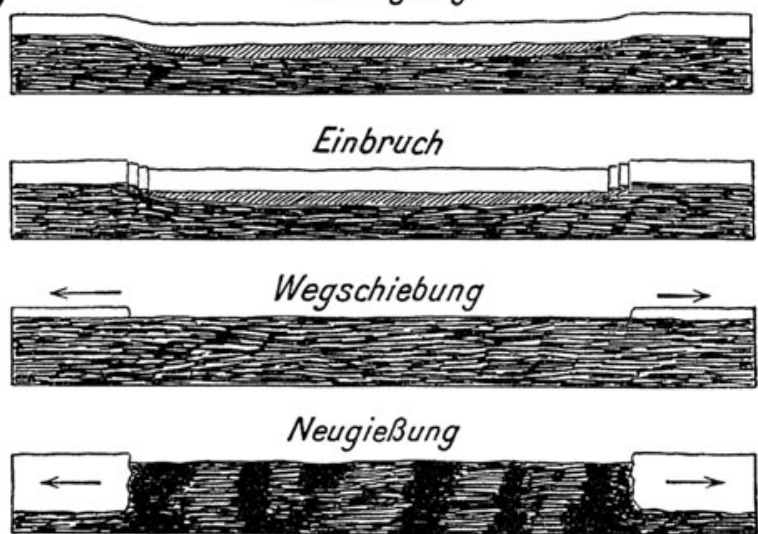

Die wichtigsten geometrisch-geologischen Möglichkeiten der Raumschaffung für die Ozeane.

(c)

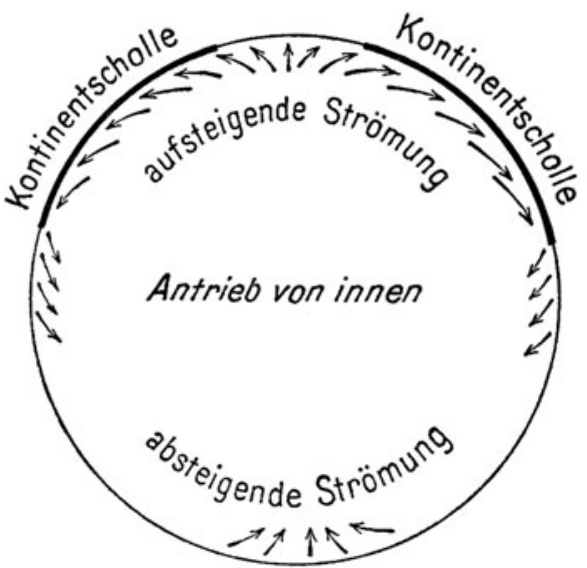

Schema von Kontinentverschiebungen durch auf- und absteigende Strömungen im Erdinnern.

space for ocean formation, from top to bottom: flexures, normal faults, stretching, and juvenile magmatic emplacement. c Stretching and breaking apart of continents by ascending and descending currents inside the Earth

considering that on this kind of continental margin, debris resulting from erosion could accumulate in great quantities, thus forming a thick accumulation of deposits becoming younger towards the ocean, and becoming folded behind because of the opposite motion. As he could not come up with any examples to support this first description of accretionary prisms, he gave up the idea.

Wegener had shown in his book that in the Earth, the compensation zone sinks deep under the mountain ranges 
because of the low density of the thick siallic rocks compared to those of the sima. With crustal rocks with a density of 2.6, the compensation zone lies at a depth of about $53 \mathrm{~km}$, whereas that depth reaches $213 \mathrm{~km}$ when the density of that same sima is taken as 2.9. Without giving further explanation, Ampferer seized on this data to establish the level at which he set the surface of the detachment zone between the superficial envelope of the Earth and its deep mobile infrastructure (Ampferer, 1925). Whether by chance or by intuition, the fact remains that it is about at this depth that the zone of partial fusion of the asthenosphere is located today. Although Ampferer had been referring to the subduction of surface strata since 1906, it was in this article that he drew up for the first time a diagram establishing a link between the movement of continental rocks and the effects of the convection currents existing inside the Earth, even if he did not state that clearly. Ampferer's diagram was published shortly before Holmes's well-known diagram (Fig. 6). Did the latter draw inspiration from it? It could very well be the case since Ampferer's article was reviewed in Nature (Holmes, 1928b). Yet we should not forget, as Oreskes reminds us (Oreskes, 1999, p. 189), that other scientists, like Osmond Fisher, had already envisaged the existence of convection currents inside the Earth (Fisher, 1889). In the same vein, A.J. Bull published an article in 1921, in which he stated in a most explicit fashion, albeit without any diagram: "It is here suggested that the folding of mountain ranges may be produced by the frictional drag of moving portions of the asthenosphere, and that these movements may be convective and result from its unequal heating by radio-active elements" (Bull, 1921, p. 364). Given that Ampferer published in his notes, only the names of the people whose opinion he was challenging, but not those with whom he agreed, it is impossible to assess whether his own opinion had been influenced by that of $\backslash$ or Bull. After the Nature review, what stuck in people's minds were the interesting propositions, laying the ground for the possibility of envisaging drifts in various directions compatible with the various trends of orogenic zones, but people objected to the author not referring to the research of scientists such as Joly, Holmes or Evans, who at the time were suggesting that deep flow inside the Earth resulted from the distribution of radioactivity. On the whole, Ampferer's contribution was viewed rather positively, but he does not seem to have left any tangible mark on the English-speaking scientific community of the time.

\subsection{Decline in the influence of Wegener's theory}

In Germany, as soon as Wegener's ideas were made public, the theory of continental drift was submitted to a barrage of highly critical reviews (Carozzi, 1985). In Great Britain, a rather similar state of affairs was established by 1922 (Marvin, 1985). In France, although it was not as widespread, scepticism clearly prevailed. This was the case particularly when it came to textbooks, although at Grenoble University, Gignoux and Moret declared their support for the theory (Gaudant, 1995). In the country as a whole, as was the case elsewhere, the debate concerned the possible application of the theory to understanding mountain building but rather the question of the faunal migration, for which it provided a more rational explanation than land bridges. In Europe, broadly speaking, even though Wegener's propositions were submitted to harsh critical review, they were always supported, and in a most consistent manner, by various competent geologists, active in their fields of research. The textbook by Holmes, Principles of Physical Geology (Holmes, 1944), often played the role of a starting point for focussing new research on new concepts. In the Southern Hemisphere, interest in the theory of continental drift (which was backed by data from the fauna and the climatology of the Perma-Trias) was kept alive through the important work of du Toit $(1929,1937)$ and later of Carey $(1958,1976)$ and King (1962). Nevertheless, these contributions coming from far-away countries were to have little impact on Swiss or Alpine geology, or in the USA. In fact, in the US, critical reviews became so ferocious that the concept of drifting continentals became the butt of jokes, ranking on a par with children's Christmas tales. That kind of reaction could be seen, up to a point, as a reaction springing out of the fear of losing bearings that once were deemed infallible. Be it out of honesty or out of scrupulousness, people refused to let themselves come under the spell of newfangled propositions which did not seem to be solidly based and had not been sufficiently tested. Combined with a feeling of superiority, reinforced by recent successes achieved in subsidiary fields, it became extremely difficult to examine those ground-breaking propositions in an impartial fashion. Following the stir caused in the 1920s, the theory of continental drift found itself terribly weakened, because it proposed theory and then sought evidence for it, and it was incompatible with the American conception of isostasy and could not produce actual concrete evidence in accordance with the principle of uniformitarianism (Oreskes, 2003, pp. 11-12). It was so weakened that de Sitter, a renowned Dutch structural geologist, could state that its advocates were an almost extinct breed (de Sitter, 1956).

In spite of this, from the early 1950s, research in the field of palaeomagnetism had established that in the past there had been considerable movement in the position of the continents. At the same time, several scientists upheld the idea, put forward by Holmes and others, that it must be convection currents which were the primary cause of the formation of mountain ranges. Various studies of seismic 
activity in the Atlantic (e.g. Heck, 1938) showed that this activity was concentrated along the length of the submarine mid-ocean ridge. In later years, the global research of Gutenberg and Richter (1954) clearly showed that the earthquakes, practically absent over vast continental and marine areas, were concentrated along narrow zones (midocean ridges, the Pacific rim) as well as a much wider zone joining the mountain ranges of Central Asia with the Mediterranean. These seismic zones were to be located even more precisely by subsequent research (Isacks, Oliver, \& Sykes, 1968), leading to the subdivision of the Earth's surface into huge aseismic regions, deemed to be rigid, bounded by zones of active faulting and seismicity. The active zones were narrow in oceanic areas, and much broader and more diffuse where they cross continental areas.

In order to clearly assess the position of numerous Alpine geologists, it might be useful to be reminded of the fact that Wegener's propositions were drawn up only a few decades after the discovery of the great Alpine overthrusts, which were to change quite radically the conception people had of the formation of mountain ranges, had been clearly identified. Those discoveries which were abundantly backed by a great number of field investigations, combined with very accurate mapping, were yet hampered by the fact that the mechanics of those great upheavals still remained a mystery. Wegener's theory, through its postulation of wide-ranging continental movements, did indeed offer some solution to the mechanism of the great overthrusts; but an understanding of the causes of such phenomena still remained incomprehensible. With the passing of the years, and in spite of the propositions of people such as Argand, Staub, Ampferer and others, the community of Alpine geologists became warier and warier of Wegener's theory. In their opinion, the latter was considered more and more flimsy. It stood too far away from concrete geological work in the field, which was still the central focus of the most active researchers in the domain Alps. Given the atmosphere of suspicion that had grown around the idea, it was not difficult for some of the leading names in geology to bring over into direct opposition a majority of people. Thus, in spite of Du Toit's contribution, or Carey's, the theory lost all its forward thrust as far as Alpine geology was concerned. In the middle of the twentieth century, it was nearly pronounced dead, although eminent scientists such as Holmes and Vening-Meinesz in Europe, as well as Field, Hess and Griggs in the USA, kept their faith in it, and continued expanding on it and bringing forth interesting propositions.

\subsection{The "Atlantis" conference, Frankfurt 1939}

Several national and international conferences broached the theme of continental drift in the course of the 1920s.
Though there were a few favourable opinions, the overall reaction was one of nearly total rejection (Ray, 2004, pp. 17-23, 2005, pp. 69-70). Objections to it were particularly virulent in the USA. Alpine geologists were noticably absent from these meetings and did not take part in any of the ensuing debates. The debates circled mainly around problems of geophysics (drift mechanisms) and palaeontology (faunal migration) rather than of tectonics. References to the structure and tectonic evolution of the Alps, the object of the most detailed research in mountain ranges, were practically non-existent. That situation clearly showed the huge gap there was between geologists who had been active in the field of the structure of mountain chains (the Argand approach, see Sect. 3.6) and geoscientists who took a broad and theoretical view of the problem (the Wegener approach, see Sect. 3.6).

The status of the argument in the German-speaking world can be measured by looking more closely at the international conference in Frankfurt am Main at the beginning of the Second World War. In January 1939, the meeting of the Geologische Vereinigung had on its agenda the problem of the Atlantic viewed from the angle of continental drift. It was on that occasion that the Gustav Steinmann medal was presented to Otto Ampferer in expression of the regard in which he was held, both as a remarkable geological explorer of the Northern Calcareous Alps and as a man who had thought deeply on problems concerning mountain ranges and their formation. Argand was invited but begged to be excused, not being able to attend. Nearing the end of his life and no more active in geology, he probably thought that he had already expressed his innermost thoughts on the subject. He was well aware that this type of debate was often shedding very new light on the subject. Little attention has been paid to this important meeting by historians of continental drift, yet it is instructive in many ways, especially as a "thermometer of opinion" at a particular point in time. Among the nonGerman participants of the conference who left a paper or a written German comment, at that time, a tradition or a rule of the Society, were two Americans, two Dutchmen, a South African, a Swede, four Swiss (A. Rittmann, R.A. Rutsch, R. Sonder and W. Staub), and a German living in Scotland (Ludwig W.E.E. Becker, born in Bonn in 1860, professor of astronomy in Glasgow from 1893 to 1935). The absence of any French or British contributors was probably related to the political tensions of the times, on the eve of the Second World War, and to language difficulties. Out of the different papers subsequently published in the society's journal (Geologische Rundschau, Vol. 30, No. 1-2, total 388 pages), 7 authors supported Wegener's propositions, 8 were in favour of his propositions though expressing strong reservations and 12 were openly hostile to them. Among the people expressing their hostility were 
to be found leading figures of German geology, such as Stille and H. Cloos. Among the people willing to accept limited horizontal movements of continents were several who were supporters of the hypothesis of "geotumors" of Haarmann and Cloos (a fashionable idea of the time), thus expressing their support for the supremacy of vertical shifts (cf. Sengör, 2003a, b, pp. 240-245).

The evidence that was brought forward by both the supporters and the opponents of continental drift seems today to be often flimsy, judged by present-day standards. For instance, for Rittmann (1939), the volcanic activity along the mid-Atlantic ridge had a chemical signature which indicated an association with cratonic crust. In his opinion, this was a "fact" that researchers ignored too often, the overspecialization of their research isolating them from the contributions of fundamental disciplines such as petrography. This stance was an illustration of the manifold interpretations that were put forward at the time, in order to account for the supposed structure of the Atlantic Ocean floor and the petrographic nature of the volcanic islands. It was mainly a way of fitting those elements into the schematizations people wanted to put forward, and very often tried to impose.

Having put the geology of the Atlantic and its environment at the heart of its debates, the aims of that conference seemed very simple and clearly set out. But all the papers showed the complexity of a situation when it came to dealing with questions concerning tectonics and regional geology (van der Watterschoot, 1939, p. 297). Many contributors went over, once again, questions Wegener had already dealt with, simply transposing them onto new objects or different locations. These new investigations which overall focused on the comparison of objects that were deemed similar, were in themselves questionable. As had occurred on previous occasions, they could not manage to provide a clear case for either the outright rejection of Wegener's ideas or for supporting them strongly. If one looked beyond the important contributions made on regional geology, what would remain were all the efforts made that were aiming at having a better grasp of the knowledge concerning the bottom of oceans. The use of echo sounders helped in reaching a better appreciation of the topography of underwater areas, of the Atlantic ridge and of the continental shelf that was often cut by underwater canyons. Yet those results did not bring any improvement with regard to the rocks and the structure of the underlying crust. Lacking a satisfactory geophysical approach, propositions such as the presence of a thin sialic crust covering the bottom of the Atlantic (du Toit, 1937) was a possibility. Van der Waterschoot was led to wonder whether the Atlantic ocean did not constitute a new morphological unit rather than a domain akin to the bordering land areas of which it would be a faulted zone (van der
Watterschoot, 1939, p. 298). The question was so new, and seemed so weird, that nobody paid any attention to it, and the same was true for the analyses of extensional tectonics (e.g. Bernauer, 1939).

Before this conference, Argand had proposed that the mid-Atlantic ridge was a kind of remnant scar of continental material. He also hypothesized that Caledonian and Hercynian folds might be found there, and, at the level of the Azores, that there might have been the presence of elements of Alpine ranges (Argand, 1924, p. 312). van Watterschoot van der Gracht (1928, p. 55) reckoned that significant masses of sial were to be found in the Atlantic, whereas his compatriot Molengraaft (1928, p. 90-92) was of the opinion that such propositions, combined with the idea of a westward drift of the Americas, belonged far too much to the realm of conjecture. He proposed that a continental rift that could be compared with the faulting and volcanic activity in East Africa preceded the formation of the ocean:

To my mind the mid-Atlantic ridge is nothing but the cicatrix of the former rent or fracture, along which the disruption of the American continent from the European-African continent took place. America drifted from the rent on which the volcanic midAtlantic ridge has been built up in a westerly direction, but Africa drifted toward its present position in an easterly direction. It has since been the site of volcanic activity, and this activity is not yet completely exhausted... If so, this mid-Atlantic fracture is strictly comparable to the great rift-valley in East Africa... If this supposition is correct one must expect to find the mid-Atlantic ridge to be composed entirely of effusive volcanic material of relatively high specific gravity. The latest measurements of gravity, rather recently made in the Atlantic Ocean above the mid-Atlantic ridge on board a submarine by Venig Meinesz, have proved that the mid-Atlantic ridge shows a positive anomaly of gravity (Molengraaff, 1928, p. 91).

The evolution of the fractures and the graben of East Africa had already been discussed by Wegener in the first edition of his book on continental drift (Wegener, 1915). Already in those days, he had pointed out that beyond Lake Rudolf and as far as Djibouti, the whole landscape was covered with basic lava of recent origin presenting analogies with the lavas found in Iceland. In the subsequent editions of his book, he presented further propositions on the mechanisms of continental drift, resting on the idea that deformation, though brittle on the surface, was plastic deeper down. However, those propositions did not offer the same wealth of insights as those of Mollengraaf, although the latter's views were to fade into oblivion. 
Referring back to the Frankfurt meeting, one has to mention the study of Bernauer (1939), who presented the results of his research carried out on recent lava fields on Iceland. He showed that over a distance of $200 \mathrm{~km}$ there had been extensional movements at the rate of 2-6 $\mathrm{mm}$ per year over the last 5,000 years. This was one of the few papers presented at the meeting that could fall within the scope of the line of research that would lead to the theory of plate tectonics. In it, Bernauer also mentioned a research project involving a broadening of the field of geodetic research which was planned for the next 2-3 years and that measurements would be repeated after 8-10 years. The war stopped such initiatives.

As noted above, on the occasion of this meeting, Ampferer was honoured. The homage that was paid to him aimed primarily at giving credit to his research in regional geology. The possible merits of his contribution to the mechanism of orogenesis were only referred to in vague and not wholly positive terms. The little credit that was granted him in that domain was also highlighted by the fact that nothing of his theoretical research was to be mentioned in the whole range of papers that were published at the time. Subsequently, he wrote a report on the meeting for his Austrian colleagues (Ampferer, 1941). He commented on the morphological data collected by the Meteor, an oceanographic vessel operating in the Atlantic, and discussed at length the morphological analysis of the midAtlantic ridge. The median position of that structure, as well as its transverse symmetry, seemed to him incompatible with the westward drift of the American continent suggested by Wegener. To him, the repeated intrusion of magmatic material at different levels along the original fault was sufficient to explain this enormous structure. The intrusions pushed the two continental rafts away from each other, as they were dragged away by diverging currents (cf. Fig. 7c, bottom "Neugiessung"). In that paper, through the use of examples, Ampferer also produced striking and very modern schematizations of the island arcs of the West Indies and the Sandwich Islands. He linked their deep trenches to important thrusts dipping to the east in front of the major east-west thrust faults. Although being in the vanguard in matters concerning the major structures of the planet, he was opposed to views that were widely accepted about the deep structure of the Alps, particularly the significance crystalline nappes. For him, the structure of the whole Alps could only be slightly different from the one he had himself studied in the Northern Calcareous Alps. There, huge flakes of sedimentary rocks, 2-3 km thick, found themselves separated from a crystalline basement that had mostly vanished, having been dragged down to the depths of the Earth. These views certainly contributed to his isolated position within the Alpine geology community. His overall view of tectonic processes in general were considered to be outdated and had little credibility. In this publication, true to habit, Ampferer mentioned only the few people who shared his views, but there was no mention of Holmes and no clear reference to the people he alluded to.

At the Atlantis conference, most of the contributors showed no reluctance in making reference to Wegener's research work, sometimes they even mentioned Argand. On the other hand, if one looks at the 383 pages published after this conference, there is no mention of Ampferer's numerous research papers on continental drift. When dealing with problems concerning the way the Atlantic was formed, which were at the heart of the debate, it would have been natural to examine this issue in the light of the various structural alternatives which he had put forward (Fig. 7b, c). That this was not the case is puzzling, since in the course of this meeting in Frankfurt, Ampferer was honoured and given full credit for the very high standard of his scientific research. It seems that his colleagues, be they geologists or geophysicists, did not appreciate at the true worth of the propositions put forward by this truly remarkable scientist. What is even more surprising is that this situation will see but very little change in the course of the decades to come.

\subsection{Dichotomy of approaches: Wegener, Argand and their heirs}

As early as 1915, Argand's research work was influenced by Wegener's propositions. From that moment onward what these two research scientists were to publish can be seen as a common appeal destined to arouse the awareness of the community of geologists to the fact that continental masses were mobile. Keeping this in mind, in the course of this paper the two names were often joined as if forming a partnership. Yet it must be stressed that their respective approaches introduced differences mostly linked to the fact that their scientific backgrounds were quite dissimilar and that each had a very distinctive form of genius.

Wegener's world was above all the world of fractures, of continental disjunctions. As he mentioned himself, it was a world-view he acquired in the course of his journeys to Greenland and through the observation of the dislocation of sea ice when rigid slabs of fast ice floated and drifted on the surface of the water without colliding except in some special places. This point of view, in which the effects of extension prevail over the effects of collision, conditioned his appreciation of the evolution of the crust of the Earth, in which light continents float on denser but less rigid rock strata forming the crust below the oceans. Given this outlook, his central preoccupation was to map out the history of faults and of continental drift. He showed scant interest for possible zones of continental collision. In its first 
edition, his book was made up of 12 chapters, and mountain ranges were barely mentioned at all. A passing reference to them was made only in two chapters of the work. In the chapter dealing with isostasy, Wegener stressed that the highest summits of mountain ranges were made of relatively light rock material, which were gravimetrically compensated by a thick lithosphere resting on the much denser strata found further down. These propositions, which he picked up from Pratt and Airy and other people who had studied the Himalayas, were presented along with a rather crude sketch showing the way the lithosphere thickens under the Alpine range. The latter idea was borrowed from Kayser who had himself been inspired by Albert Heim (see Schaer, 2010). The examination of mountain ranges in the light of the fact that this thickening of the lithosphere was thought to be linked to the presence of major thrusts and folds was to be found in only one other chapter, focusing on the study of oceanic trenches and island arcs. Accumulating in nappes and flakes, the greatest part (95\%) of these light rock materials found themselves pushed downwards where they became plastic and deformed even further. In the later editions of his book, Wegener nevertheless enlarged a little more on these first scanty allusions to the formation of mountain ranges. He granted the phenomenon a little more attention in spite of his initial indifference. In 1936, in the last edition of his book, his commentaries were further expanded, using ideas taken from Argand's work. Yet the whole book remained focused first and foremost on the breaking apart and drifting apart of continental masses. Nevertheless, it is true to say that his knowledge in the field was rather limited, although even in the first edition of his book, he mentions the structure of the Alps and refers to the research work Heim, Bertrand, Haug, Schardt, Lugeon, and even Ampferer and Hammer. The range of references was quite striking, coming from a scientist that was considered as rather ignorant in the field of geology.

As for Argand, when he committed himself to working on the problems raised by the idea of continental drifting, he was a well-seasoned field geologist who was highly regarded for his work in map-making. Both his detailed map-making and his broad-sweeping views about the Penninic zone of the Alps proved very successful. This line of approach led him first and foremost to the study of the geometry of great overthrusts and recumbent folds, implying collision and significant crustal shortening. $\mathrm{He}$ was a fiery advocate of the idea of the formation of nappes as recumbent folds with extensive reversed limbs. This was an idea he vigorously campaigned for in his early days, when he was still studying medicine. He put forward the idea that those units, like any living creature, had undergone from their very beginnings a form of evolution that was rigorously controlled, i.e. "embryotectonics", whereby the first deformations developed and in the end brought out the mature structures. As the years went by, perhaps due to the influence of Wegener's research work, Argand was brought to admit that the geometry of the collision zones and the nature of the rocks they were made of must have been in a state of never-ending evolution. These considerations, which were barely compatible with his former approach that had brought him such fame, led him to give up his original idea. In his last work, once again under the influence of Wegener's contributions, he was won over to the ideas of extensions and rotations. He introduced those ideas successfully and applied them to the development of so-called geosynclinal sedimentation and to interpret the evolution of the Mediterranean domain. The deformations that are linked to continental collisions are not only apparent in the eroded orogens, they also affect the interior of continents in the shape of basement uplifts characterised by large faults and fractured domains. The geometrical structural model of the Alpine range he put forward would be retained for a long time after the theory of plate tectonics had been accepted. The propositions of continental drifting Wegener had introduced would later find application in the field of palaeographic reconstructions which appeared even before Alpine geologists had fully accepted plate tectonics, but much more so once the new ideas had become part and parcel of Alpine geology.

\section{The advent of plate tectonics}

\subsection{View from the European sidelines}

In the wake of the remarkable gathering of geological data that The Face of the Earth (Suess, 1921) had represented, it seemed, at the beginning of the twentieth century, that the time had come to take a new look at the history of the Earth. Although placed in very different perspectives, both Wegener's Origin of the Continents and Oceans and Argand's Tectonics of Asia, seemed to be in the position of playing such a role. In contrast to Suess's book, which remained deeply rooted in concrete data, Wegener's and Argand's contributions called upon imagination and were subjective and selective. As Termier comments on Argand's great synthesis:

Some people will say: this is pure unadulterated Eduard Suess. True enough, I am quite ready to admit it, there is the genius and the loftiness of tone of some of the best passages of Suess. But Suess was far more guarded in his approach; he was at his very best when cutting down to the bare minimum the number of hypotheses he was presenting... In the case of Argand, the approach is rather different. He launches 
headlong into unchartered territories. He finds himself at ease in this world, and the whole thing seems at first glance quite extraordinary, but when one comes to looking at it more closely, it becomes clear that, most of the time, the world he inhabits belongs entirely to the realm of the imagination. (Termier, 1926, p. 172).

After the lack of consensus on the validity of Wegener's theory, one had to wait until the late 1960s to see the theme of continental drift make its way back into general consciousness, within the framework of plate tectonics. Initially, the steps taken which led to the emergence of this new paradigm did not in any way aim at replacing the previous theory, nor did they aim at papering over the existing cracks. The theory was born out of a desire to explore and draw up a full inventory of all the parameters of the ocean, both in the fields of chemistry and physics, mainly for strategic purposes. It is out of the mass of collected data that very soon an unexpected image of the dynamics of almost three quarters of the surface of the globe was to emerge. Continents played but a passive role. It was thus normal that field geologists, at first, did not play any part in those proceedings and the various proposals that came along with it. Very often, they even declared their hostility, or at least their reticence towards the conclusions reached by scientists who understood perfectly well the problems connected to the world of oceans and physics, but had sometimes a very limited grasp of the problems of rock formations. Yet among the latter were several who had been given a solid training in geology. The same could not be said of field geologists who had but scant knowledge of the leaps forward which had been made in geophysics and its instrumentation. Between the two communities, the geophysicists and oceanographers on the one hand, and the field geologists on the other, the possibilities of a dialogue were at the time very limited. In 1959, on the eve of this revolution, Goguel made a brilliant assessment of the problem. The study of the physical structure of the earth...

...got under way thanks to the setting into operation of a series of very particular methods, today we have reached a point where it seems it has become a selfcontained discipline. Geologists limit themselves to using its results, or shall we say, at least some of its results. This dissociation, like all divisions that the complexity of science tends to increase between the various fields of diverse specialisations, does not come about without its drawbacks. The march forward of science sometimes finds itself stopped or slowed down, not so much because the specialists are ignorant of the results achieved in other disciplines, but because they find it extremely difficult to assess how far reaching they are and the degree of credence they should be given. That difficulty is alive, particularly between geologists and geophysicists, whose respective disciplines operate using radically different methods, naturalistic on the one hand, and physical on the other hand. (Goguel, 1959, p. XII).

Although Goguel had a very wide knowledge of geophysics, his hesitations when it came to the problem of continental drift are referred to in the two editions of his Traité de tectonique (Goguel, 1952, 1965). In his opinion, though the theory of continental drift was not the perfect answer, its merit resided in the fact that it offered a solution when considering the major zones of crustal shortening one observes in mountain ranges.

But if nothing were to remain of the picture Wegener drew up of continental drift, his theory will have proved useful in as much as it compelled geophysicists and geologists to consider the possibility of important lateral movements of some parts of the crust of the Earth, movements which are necessary if we are to explain how the formation of mountain ranges came about. (Goguel, 1952, p. 350).

Continental drift represents a hypothesis, and numerous research teams work in favour of its advancement. As for us, our opinion is that, at present, adopting it or rejecting it would be like professing a kind of act of faith, which as such is irrelevant in this matter. But the situation may change. (Goguel, 1965, p. 397).

Being an active geologist in the Alps, Goguel remained convinced that the solutions concerning the evolution of the surface of the Earth through space and time were still to be found through research in the field of geology and not of geophysics:

The hypothesis of convection currents opens up a wide range of possibilities in order to throw light on all the data tectonics enabled us to gather (Goguel, 1952, p. 356).

But because of its very flexibility, that hypothesis does not seem susceptible of leading us to precise rules when it comes to the position of orogenic zones, or their distribution in time. On the contrary, it is to geological analysis that we have to turn to if we want to be informed of the broad directions in the history of convection currents (Goguel, 1952, p. 360).

Very few scientists combined the two disciplines to a sufficient extent. An exception was Tuzo Wilson He was a geophysicist who knew how to make use of all the experience he had accumulated as a field geologist specialising in the deeply eroded part of the Canadian shield that had 
remained unaffected by later deformations. From this experience, he became convinced that the internal part of the plates were perfectly rigid.

When plate tectonics was first propounded, most Alpine geologists thought it was subject to the same flaws as Wegener's theory. They had the impression that it was dominated by uncontrolled speculations, and that, in addition, it was mainly applicable to zones of the Earth that could not be submitted to direct scrutiny. Their scepticism was further reinforced by the fact that this approach was dominated by techniques about which they were quite ignorant. Being at home with the rocks and the fold structures of the mountain areas they had investigated, they went as far as accepting that the new theory might shed new light on the question of ocean formation. However, at first, they were often opposed to the idea that it could lead to positive developments that could help them find a solution to the riddles they found themselves faced with inside the continents. They were not ready to abandon the idea that momentous geological discoveries could only come about thanks through field work, through direct contact with rocks, involving great physical exertions that only those with extraordinary stamina could endure. Over a long period of years, and even to this day, geological research conducted at high altitude, or in isolated arid parts of the world, where rocks are well exposed, was and is tied to a sacred seal that could facilitate success in geological research, carried by independent individuals, working on their own. In contrast, research carried out at sea, required the presence of multi-disciplinary research teams working with sophisticated and highly expensive equipment, which was constantly on the way to obsolescence and in need of repeated updating. In Switzerland, the diffidence shown towards the new theory found itself reinforced by the very little interest established geologists expressed in geophysics, a discipline that was to remaining in a pretty parlous state in that country for many years.

\subsection{Late development of geophysics in Switzerland}

After the studies of the variations in gravity in the Alps and in Switzerland which were undertaken by the Geodesic Commission and reviewed by Heim (1919-1922), one had to wait until 1934 for the establishment of an embryonic group that was to be active in the field of geophysics at the Swiss Federal Institute of Technology (ETH) in Zurich (Pavoni, 1965). Underpinning this mutation, the person who was to be the pivotal figure, Fritz Gassmann (1899-1990), was a mathematician who was interested in the propagation of waves in porous media (Pavoni, 1990). He was first appointed to teach geophysics as an external teacher (Privatdozent), while he was employed as mathematics teacher in the gymnasium in Aarau. It was only in
1942, when the Institute of Geophysics at the ETH was officially set up, that he was appointed as its head, with the rank of full professor. This favourable evolution was made possible through the active support of the petrography professors, Paul Niggli and Alfred de Quervain. These were two established figures who were more in favour of a quantitative approach in the field of earth sciences than geologists were at that time. In paper published in 1950, Gassmann (1950) set out the goals for this new structure. The teaching and the research that were to take place in it, aimed at giving future geologists, particularly to those destined for the oil industry or mining and ore prospection, practical knowledge of the elements of geophysics used in those activities. They were to become familiar with these through lecture courses, and also through practical field work. The group was thus set up as a service centre, whose research, be it theoretical or practical, was to be aimed at improving petroleum and mineral prospection methods. This course of action was pursued in accord with physicists mainly involved in the fine tuning of new pieces of equipments. Ties with geologists were of a rather tenuous nature. One geologist, N. Pavoni, was later to commit himself to working within this group, but only from 1959 onwards. This move came from the geophysicists and not from the geologists. The first geophysical research published by the journal of the Swiss Geological Society was in the mid-1940s, after many years of its existence (Gassmann \& Prosen, 1946; Niggli, 1946). The creation of a series of geophysical monographs as a contribution to the geological map of Switzerland as late as 1957 makes it clear that there was but scant interest within the ranks of the Swiss geological community for a strong development of this new discipline. The clear bias of the Zürich students in favour of applied geophysics and prospection, as it was put into practice by Poldini in Geneva and Lausanne (Meyer de Stadelhofen, 1967/68), probably did very little to focus the attention of Swiss geologists on the issue of plate tectonics. The interesting initiatives of Paul-Louis Mercanton in Lausanne, including his involvement in the field of palaeomagnetism (Renaud, 1963), suffered the same fate. The scarcity of available resources, as well as the fact this scientist was trying to do too many things at the same time, set a limit on his research impact. However, the weakness of geophysics in Switzerland, and the lack of interest which Swiss geologists showed for the new discipline, was not an isolated case among European nations at that time.

\subsection{The slow awakening}

Unlike their U.S. colleagues, Swiss geologists expressed deep reservations when the idea of plate tectonics was first presented (Trümpy, 2001; Schaer, 2003). Yet several 
conditions seemed to concur in favour of the acceptance of the new theory. Wegener's theory of continental drift had certainly contributed to eliminating the element of surprise, and deep down a feeling of sympathy still seemed to linger on, bringing people to support the idea of continental drift. Those ideas had set ancient riddles in a far better perspective. In addition, there had been the propositions coming from well established geologists like Argand, Ampferer, Holmes and others, which most well-informed Alpine geologists had probably read about or heard of. Yet this apparently favourable environment was not enough to quickly convert many to the new theory. Their attention was riveted on issues they deemed to be at the core of their science at the time, and they refused to commit themselves to an approach they found too speculative and too remote from their main centre of interest. In their opinion, the "new global tectonics" was too dependent on geophysics, and too rooted in the exploration of marine zones, to offer any new prospects for the kind of research on mountainous continental areas which was their domain. One can clearly see the great difficulty there was in changing course. They were the heirs to a tradition that had made their discipline very famous and very popular in their own country. As noted above (Sect. 4.2), they were of the opinion that geophysics was an applied science, and a minor one at that, which could in no way rob them of the pre-eminence that was theirs when it came to formulating theories on the formation of mountain chain, or make any significant contribution to that field. They were of the opinion that they had to limit their activities to fieldwork of the kind that led them to the discovery of the Alpine nappes and subsequently to detailed palaeographic reconstructions such as those of Trümpy (1960), two achievements which enabled them to make of their mountain range a greatly envied model. Therefore, it was not really surprising that the majority of Swiss scientists working in the field of Earth sciences were sceptical when the theory of plate tectonics was first propounded. In general, a certain scepticism-some would say, a healthy scepticism-was to remain alive for many years, before slowly fading as the revolution consolidated.

Following the first formulations of the concept of plate tectonics, the few geologists who tried to apply it to the evolution of the Alps came first and foremost from groups out of which the theory had originated (e.g. Hsü, 1971; Dewey, Pitman, Ryan, \& Bonin, 1973). The ideas they put forward very often met with a cold reception on the part of the great majority of Alpine geologists, or were not rejected outright, judged to rely on a body of knowledge of which a part at least seemed clearly open to criticism. The spearhead of acceptance was provided by Hans Laubscher, professor of geology at the University of Basel, who quickly committed himself to the new line of thinking.
After many years working in the oil industry, this field geologist, whose training ground had been the Jura mountains, had broadened his approach to geology through close ties with geophysicists and other research scientists who were attracted by a quantitative approach to geology. In 1965, he took part in a symposium organised in Canada by "The Upper Mantle Committee" (Menard, 1986) where he showed that the recently discovered oceanic transforms were closely analogouss to structures known for a long time in the Alpine domain or in the Jura mountains (i.e. strike-slip faults associated with major thrusts in compressional regimes), and in 1969 he first applied the new ideas to Alpine-type mountain building (Laubscher, 1969).

Subsequently, Laubscher published several papers in which he integrated the ideas in favour of mobility contained in the theory of plate tectonics with Alpine tectonics and produced new kinematic models (Laubscher, 1970, 1971a, b). The available data led him almost immediately to give up the concept of geosyncline in favour of the idea of the evolution of extensional continental margins bordering typical oceanic zones. As the deep heavy lithosphere was sinking down, masses of light crustal material were floating and colliding, locally incorporating oceanic crust in the shape of ophiolitic flakes. His research followed by similar work by other field geologists gradually weakened the resistance of the local geological community with regard to the application of the new theory to Alpine relationships. Laubscher's models were accompanied by particularly clear and suggestive graphics and integrated Alpine geology with a whole new range of geophysical, petrological and geoschronological data.

Another prominent forerunner of applying the new theory to the Alps was D. Bernoulli, now concentrated on the analysis of the sedimentary sequences in the Mediterranean area, in comparison to sediments in the Southern Alps, as well as those found deep within the Alpine range. His work turned out to be a major contribution towards bringing the community of Alpine geologists round to accepting the plate tectonics. He established that a large proportion of the sediments from the Tethys was associated with deep pelagic deposits which proved to be very similar to the sediments that had been collected on Leg 11 of the Deep Sea Drilling Project. His model for the evolution of the Mediterranean area (Bernoulli, 1972, 2001) showed that continental margins in which at first carbonate reefs had settled, when moved further out to sea, gave way to zones affected by extension tectonics, and that sedimentation sometimes took place directly on oceanic ophiolitic deposits. Those turbiditic sediments became mixed first with more argillaceous limestones, then with a typical facies called "Majolica/ Biancone" in which a particularly active differential subsidence of continental margin can lead to deposits of radiolarite. These observations and considerations made a 
major contribution to the confirmation of continental mobility, in this case through sedimentological research and comparison with deep sea drilling results (Bernoulli \& Jenkyns, 1974), and was instrumental in making plate tectonics a major tool for interpreting Alpine relationships (cf. Bernoulli, 2001, Bernoulli \& Jenkyns, 2009), and, conversely, in making the Alps into a major object for validating the new theory (cf. Milnes, 2009).

\subsection{On the power and limitations of imagination: words and images}

When it came to Wegener's propositions about continental drift, it was mostly creative imagination that played a pivotal role. The same could be said of Argand's late works.

The latter, through the magic of words and graphics, exploited to the full the perspectives opened up by the use of parameters he deemed essential. His approach rested upon the use of continental data, but his ultimate aim was to develop an the overall model of the kinematics of the earth. The limited knowledge available at the time did not provide him with the integrating power of plate tectonics. Yet it did open up several innovative prospects. His ideas were backed by numerous illustrations that were endowed with great suggestive powers (see Schaer, 2010; Figs. 4, 5, $6)$. Sometimes, the success of his propositions almost transformed them into scientific truth, which managed to impose itself on observations in the field. Such was the fate of Argand's presentation of the development of the Alpine orogen with time, with its sequence of thirteen illustrations (Argand, 1916; see Schaer, 2010, Fig. 4, for an illustration from that sequence) as if he had frozen on a single plate the continuum of Alpine evolution. His presentation became a standard work, one which impressed its logic on each of the numerous geologists who were attracted by the idea of "embryonic tectonics".

As Le Grand (1988) underlined, graphic illustrations similarly played an important role in the presentation and acceptance of plate tectonics. However, in this case, the gap between the large amount of data available and the pictorial presentations left far less room for the imagination (e.g. the outline of the plates based on seismic zones, the morphology of the ocean floors, the location of oceanic transforms, etc.). It was the simplicity of the temporal development of the oceanic domains that allowed the presentation of such a clear image in which one could read, almost without effort, the evolution of two-thirds of the surface of the Earth over the past 165 million years. Continental zones whose structural evolution had been quite recent could still be integrated rather easily into this pattern, although it was much harder to get a clear picture of the more distant past. Ancient orogens, therefore, were to be ignored for a while. The fact they were left aside did not hinder the application of the model and its dominant position spread in no time to almost every field in geology.

In 1913, when the International Geological Conference awarded its highest distinction, the Spendiaroff Prize, to Argand for his precursor monograph, "Les nappes de recouvrement des Alpes Occidentales" (Argand, 1911), it departed strongly from the criteria it had set itself for the award, that it should be "a critical study of the fundaments of the theory of large-scale overthrusts" ("étude critique des bases de la théorie des grands charriages"). In effect, the members of the jury awarded the prize to this work mostly for its graphic illustrations, which were such a brilliant presentation of the great Alpine overthrusts that its impact went far beyond a theoretical critique of the phenomenon. In a certain way, Argand's opus magnus, La Tectonique de l'Asie, together with La Carte Tectonique de l'Eurasie attempted a similar operation (Schaer, 2010). Unconsciously perhaps, Argand came to the conclusion that, given the fact that the theoretical knowledge we had of the dynamics of the Earth was inadequate and did not enable him to provide an answer to the question of continental drift, the views he was expressing would have to impose themselves through a particularly commanding presentation of the recognized continental structures. A convincing graphic representation of the structure of the Earth seemed to him the best method of communicating its complex organisation and how he believed it functioned. If the nut proved too tough to crack, he called upon his phenomenal imagination and his mastery of words to set the facts and possible interpretations in a sequence of evocative and coherent images. The attempt was only partially successful. The book was much admired because of the mastery of its author, but nevertheless, as we have seen, it did not lead anywhere in the end. Some of the illustrations and much of the text seemed too new and too far removed from the accepted facts of the day, that the scientific world could easily draw from it material that would further enhance the worth of its own contribution.

The rejection of the idea of continental mobility found itself reinforced by two main themes which blocked progress and were shared by a great number of people within the community of geologists active in the field, among them those active in Alpine research. On the one hand, the majority of geologists were of the opinion that in order to grasp the essential principles concerning the dynamics of the Earth, in space and time, nothing was better than field work carried out in mountainous areas, above all when the latter was backed by rigorous map making. In this context, the methods of geophysics were of little help, because they depended far too much on parameters and ideas over which one had no control. "In order to improve Wegener's theory and make it endure in the long term, to remove the 
implausibilities it contained, one just has to wait for the geophysicists to come up with something. They were bound to conjure up no end of hypothetical schemes, new details of the great "machine", as Pascal put it, details to which one might not be able to give any more credence than to the previous details, and which in any case cannot be checked." (Termier, 1923, p. 17).

On the other hand, although they concentrated on finding solutions to local problems, most Alpine geologists were also convinced that they were involved in fundamental research. The structures and processes they were laying bare would repeat themselves in the other mountain ranges present on the face of the earth, and thus were of significance far beyond their original regional framework. Because of the comparisons they make possible, they opened up avenues for the comprehension of the whole Earth. "As research moves forward, doesn't it set out clearly the guidelines for a history of the deformation of the planet, and if one were in a position to narrate that history in exhaustive detail, wouldn't it bring tectonics to its natural culmination?" (Argand, 1920, p. 13). But the Alpine model certainly has its limits, and, as is often the case, success can blinker one's views, preventing the perception of subsequent, new, developments. Although, for many geologists, the evolution of the Alps, which was particularly well documented, remained a unique model of the way one could carry out the analysis of orogenic phenomena and as such couldn't just be brushed aside, there were many who thought that it was but one particular example in a whole range of endless variations. The reasons for the great variety of orogenic evolutions remained largely unfathomed, and only later became the focus of research on the comparative anatomy of mountain ranges (e.g. Schaer \& Rodgers, 1987). As Lemoine (2004) suggests, the rejection of the idea of a mobility extending beyond that of large overthrusts, affecting whole continents, could also be due to fear of the unknown, to resistance to change, and to the preference one could express in favour of things that were supposed to be part of a well-known universe.

During the first half of the twentieth century, very few geologists were aware that the earth-shaking tectonic revolution that was later to become the hall-mark of the epoch, would be closely linked to oceanographic research, a field that for most of them, at best, was viewed as of secondary importance. Concurrently, very few geophysicists who took part in the adventure, realized the extent of the upheaval that was about to be caused in the whole Earth Sciences by their results. Many of them were far less concerned about the issues that geology had to deal with than about those that physics had to face while this great undertaking was taking place. They only showed a moderate interest in integrating the data they were gathering into a new presentation of terresrial dynamics. Some of them were even to remain opposed to the idea of continental mobility for a very long time (Sclater, 2003). The latter author notes that it was the fact that scientists like Hess and Wilson had been trained as geologists, and had had practical experience in geological field research, that proved a decisive factor in reversing the trend. More often faced with the necessity of synthesizing and identifying new suggestive themes than the physicists, it was the people who had been trained as geologists, above all those who had had some practical experience in the field, who had a clear advantage when it came to dealing with new perspectives. On the other hand, their physicist colleagues, thanks to their long tradition of experimentation, brought along essential skills in drawing up simple models that could be tested easily and applied predictively. However, few of them had an interest in continental geology and it is not surprising that the propositions of, for example, Wegener, Argand or du Toit, were ignored for a far longer period than those of Holmes or Hess.

In the whole field Earth Sciences, the period of transition from continental drift to plate tectonics bore the stamp of an approach that became increasingly quantitative, and more and more frequently turned to physics and chemistry for answers. In spite of this trend, up to the 1940s, the outstanding contributions came from eminent scientists working very much on their own, such as Ampferer, Wegener, Argand and du Toit. The first quantitative approaches, also carried out by loners, did not bring many new results and sometimes even clouded the clear perception of the more speculative contributions (Jeffreys, 1926). When Holmes (1928a) put forward the idea that the presence of radioactivity in the mantle implies the existence of convection currents, the models were still largely a product of his imagination, combined with the propositions of other inventive scientists.

The large transformation that was to lead to the theory of plate tectonics was effected by scientists exploring fields of study that had been little known and often ignored by geologists, such as paleomagnetism and physical oceanography (for an analysis of research in uncharted fields, see Oliver, 2003). As they were faced with the challenge of analyzing objects that were not visually within direct reach, they resorted to technological devices enabling them still to gather significant quantitative data, which they strove to collect over the entire world. The comparison and synthesis of data originating from diverse disciplines (paleomagnetism, seismology, heat-flow, gravimetry, radiometric dating, marine geology, etc.), but which were all very necessary for establishing plate tectonics, was carried out by scientists with broad overall views and not averse to the speculation. It must be noted that the first clear formulation by Holmes of the way oceanic crust formed on oceanic ridges, and its sinking into the mantle at the oceanic 


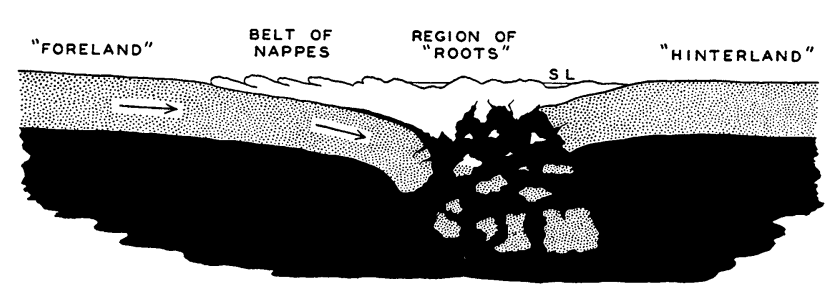

Fig. 8 Illustration of the formation of a mountain range during continental collision with the plunging and disintegration of the upper crust (subduction) into deeper levels of the Earth (Daly, 1942)

trenches (Holmes, 1944), preceded the vast accumulation of geophysical data during the post-war period. This was also the case for Daly's bold illustration (Fig. 8), showing that the continental displacement contemplated by various scientists entailed the sinking of the crust into the mantle (Daly, 1933). Hess (1962) published a paper concerning the history of oceanic basins which was both fundamental and prophetic. It is a perfect illustration of the power of the imagination when it is put in the service of integrating a whole range of diverse data into a coherent whole, in this case including data from petrology, a discipline of which he had been a practitioner before his stint as a marine geologist during the Second World War. His approach was global and was based on simplifications which contained what he considered to be the essential points. Hess was convinced of the validity of his main propositions, but he was also aware of possible errors and possible hostile reactions. He therefore presented his work as a tentative attempt in "geopoetry". Relying on manifold quantitative data, he introduced the idea of sea floor spreading, in which an oceanic crust of serpentinite acted as kind of conveyor belt on the floor of the ocean, originating along the midocean ridges and sinking down into the mantle at the trenches. What had been for its author a hypothesis structuring his research, very quickly became the pattern of reference into which researchers in various disciplines tried to fit their own results. The integration of such diverse elements, such as the interpretation of palaeomagnetic data, the concept of transform faults, the geometry of the rotation of rigid plates on spherical surface of the globe, the dropping of serpentinite in favour of basalt as the main constituent of the oceanic crust, led to the formulation of the theory of plate tectonics during the period between late 1966 and early 1967. Convincing illustrations imposed themselves, first in the form of planar sketches, then in the shape of spherical models, integrating data that were becoming more and more accurate. Over a very short span of time, the new theory became the reference model into which geological phenomena on the continents were to be integrated, and, very soon, the inevitable prism through which they had to be presented. The hypothesis of continental drift had undergone a very different kind of process.
It had been proposed at a time when the geological community was still poorly structured (Lemoine, 2004) and when geological research was most of the time hampered by its local roots. It had not been revitalised or changed by independent data that could be gathered across the whole of the globe. The only facts originated from the mapping of the geology and morphology of continental areas, often quite local and incomplete in nature, and at the same time it was subject to barrage of criticism coming from researchers saying that it was mechanically impossible.

The research that led to the theory of plate tectonics was mostly carried out by researchers in two English-speaking countries: the USA and the UK. The international tensions existing after the Second World War made it relatively easy to find the large amounts of money necessary to carry out research in oceanography and seismology. Outstanding leaders, such as Ewing, Revelle, Menard and Bullard, directors of oceanographic institutes and land-based geophysical research laboratories, found themselves in favourable circumstances for them to bring about the scientific progress in their special areas. They were remarkable in the way they stood by the teams of young research scientists, all well-versed in geophysics, and spurred them on, committed to deepening knowledge of everything that had to do with the marine domain. They made sure it would happen. Theirs was a decisive role. To establish the legitimacy of his theory, Wegener used data from the geological literature, not of his own making, and the most important facts had been known for a long time. In contrast, the theory of plate tectonics originated from within the very community of scientists who had been carrying out the research leading to its formulation. Up to a point one could say that it was the images that the data gathered about the ocean domains brought to the fore, even though they had been gathered for other purposes, rather than the flashes of inspiration of individual research scientists, that brought about its blossoming.

The geological exploration of oceanic depths could not be carried out through direct observation, it was done through the use of very sophisticated machines capable of systematically collecting indirect quantitative data over large areas or of direct sampling at isolated points. In order to undertake that research one had to turn to scientists and engineers coming from various highly specialised fields (seismology, magnetism, heat flow, geochemistry, sedimentology, palaeontology, etc.), working in a spirit of cooperation - a work atmosphere far removed from that of solitary field geologists, working very much on their own, analysing and describing the rocks and the landscapes which surround them. The Earth Sciences had entered the age of ambitious interdisciplinary research projects involving enormous budgets, large instruments, complicated logistics. This process directed research more and 
more towards a rational quantitative approach, leading to a fundamental questioning of the role of field geology and of the relevance of map-making. The latter activities found themselves more and more brushed aside and replaced by indirect approaches, with more and more sophisticated technological devices turning out larger and larger quantities of facts and figures. This data was subsequently fed into powerful computers that could deliver clear appraisals, providing parameters could then be compared to those of the models they had themselves contributed to setting up (Dewey, 2003).

At first, it seemed likely that this trend would continue. However, after an initial period in the doldrums, field research has been given a new lease of life and is taking a closer and more rigorous, goal-oriented look at the patterns of relationships existing between rocks and their environment. With the advent of plate tectonics it soon became clear that, far from being an obsolete and old-fashioned activity, field geology remained an essential tool for studying the Earth, combined with the specialised tools of sedimentology, stratigraphy, structural geology, petrology, radiometric dating, etc. It also became clear that it is just as important for geophysicists and oceanographers to learn to know and respect the results of field geology as it is for geologists to learn to know and respect the results of geophysics and oceanography. Hence, since the 1970s, there has been a increasing number of mega-projects with a geological input which was at least as important as the geophysical experiments. An early example was the European Geotraverse (EGT project, 1980-1992) from North Cape to Tunisia, passing through Switzerland, which started as the germ of an idea in the heads of two towering geoscientists based in Zürich, the geophysicist Stefan Müller and the geologist Rudolf Trümpy (Blundell, Freeman, \& Müller, 1992). Later projects such as ECORS (France), CROP (Italy) and NRP 20 (Switzerland) fall into the same category (Roure, Heitzmann, \& Polito, 1990). Today, interdisciplinary geoscience projects, integrating the geology and geophysics of continental areas, are the rule rather than the exception. Field geology in the Alps before plate tectonics may seem to have been an idiosyncratic occupation of loners, nature lovers and mountaineers, but, looking in the back mirror, it lay the foundation for the Alps and other mountain chains to become important natural laboratories, where features deduced by indirect means under the oceans or in the deep lithosphere can be described and sampled, and subject to direct observation.

\section{Overall considerations and conclusions}

The theories of continental drift and plate tectonics came upon the world as a surprise, each postulating the mobility of continents on the surface of the globe. They have often been presented as twin theories and parallels have been drawn between the two. Yet there are great differences between them when one considers the way they came into being, and the way they argued their respective cases. When it came to the way they were treated, there are very obvious analogies as well as important discrepancies.

Continental drift was the brainchild of one man, Alfred Wegener. Although he was often accused of engaging in wild speculation ("geopoetry", "geophantasy"), his thought process was as near to what has been called "to speculate in a controlled way" (Milnes, 2009) as could be achieved at the time. Though several scientists had reached identical conclusions before Wegener, he was the first who knew how to make the best possible use of a wide range of well-known facts in the field of the earth science, which he combined with a few new elements. He gathered these together into a self-consistent whole and introduced a new perspective that was both coherent and easy to grasp. Presented in this way, the new theory could not be ignored, all the more so since it was casting serious doubt on several fundamental concepts, which up to then had been taken for granted. The new theory proved very popular because of the new perspectives it opened up, but it was also much disparaged because of its boldness and the flimsiness of some of its arguments, especially those related to the mechanical causes of continental mobility. A good deal of the stir caused by Wegener's propositions came from the fact they were introduced at the very moment when a growing number of geologists were becoming aware that the theories they relied on to explain the dynamics of the Earth were useless. The very simple and evocative image of the way coastlines fitted together on both sides of the Atlantic carried forward the new theory. It was further strengthened by throwing relevant new light on several issues that up to that moment had not been well integrated into a general view of how the planet had evolved, particularly the distribution of Permo-Carboniferous glaciations and other palaeoclimatic zones in the Southern Hemisphere, and the analogies found in fauna presently scattered over the surface of the globe. In order to vindicate his propositions and in spite of the being a meteorologist and geophysicist, Wegener mostly called upon geological features and considerations, which had become established long ago but were looked at from a new angle. His approach to the different gravity fields observed over continents and over oceans proved particularly fruitful, but it was very slow in asserting its supremacy. For instance, on the eve of the Second World War, Gutenberg and Richter (1939, pp. 322-323), two scientists that were particularly competent in the field, were still of the opinion that a very thin continental crust covered the bottom of the Atlantic and Indian Oceans. Later, Gutenberg (1951) was 
still maintaining that there was the possibility of finding sialic material in some parts of the Eastern Atlantic. It was only thanks to the research carried out by Ewing and Press (1955) that it became established beyond doubt that oceans should be considered as belonging to a world that was totally independent from that of continents.

Most Alpine geologists expressed deep scepticism when it came to taking Wegener's theory into consideration. Although they found it attractive, it seemed to them too speculative and too far removed from their concerns. In their opinion, it paid too little attention to field work and rocks, which for them, along with construction of geological maps and profiles, constituted the very core of their discipline. Yet two geologists, Ampferer and Argand, followed to a certain point by Staub, committed themselves to making a plea in its favour, and to campaigning for its promotion. Ampferer had in fact anticipated Wegener's ideas, and, as early as 1906, had suggested that the folds on the surface of the Earth were due to the movements of material within the Earth. He was to take up again some of Wegener's propositions, reappraising them and bringing them even closer to the perspective that the theory of plate tectonics would later adopt. He was to provide clear examples of subduction and he would also show how basic rocks had repeatedly settled into place on the bottom of oceans (see Fig. 7). However, Ampferer's approach was clearly different from that of Argand, the second protagonist. Ampferer thought that through the knowledge and thought he was bringing to the defence of the new theory, he could improve on it. Argand wanted to illustrate its validity by considering the geological evolution of the Alpine chains, the continents bordering the Mediterranean, and the whole of the Earth. These approaches and advances were to be ignored by the scientists that would eventually carry out the research leading to the theory of plate tectonics, probably due to very few of them being familiar with Alpine literature, especially that written in German. It was even more the case for Ampferer, whose theoretical contribution was often considered as of very dubious quality by his peers, and who, as a member of the Austrian Geological Survey did not benefit from the stimulation and support which regular intercourse with students could provide.

Argand had been very quickly attracted by Wegener's ideas. They fit so well with his own ideas of generalised mobility, but he had difficulty properly acknowledging the support it gave to his ideas in his publications, since they came from outside the field of his own research. However, all his work had been concentrated on the dominance of the phenomenon of crustal shortening during the formation of the Alps, on which his propositions of "embryonic tectonics" rested. With the influence of Wegener's work, Argand also came to realise the importance of the phenomenon of crustal extension. Under conditions of extension in the continental crust, flakes of heavy oceanic rocks came into being, and, on top of them, deposits of bathyal and abyssal sediments, mixed with deposits originating from zones that were not as deep, brought about by deepwater slumps, accumulated. The "geosynclines" with typical sedimentation in huge depressions born out of a crustal flexure, seemed to have become obsolete, although Argand did not entirely discard this classical concept. In the same way, when it came to explaining the presence of mafic rocks in between the Pennine nappes, he did not discard the idea of the presence of stretched basic intrusions fed by "the sub-continental sima" "the emplacement of these rocks was essentially guided by kinetics" (Argand, 1934, p. 186). The sketch proposed to illustrate the ophiolitic sutures between the continental masses stressed the influence of tectonics (Schaer, 2010, Fig. 5). Argand's two prophetic propositions, the one concerning ophiolitic sutures and the other concerning the extensional nature of oceanic basins, were to be ignored by both Alpine geologists and the advocates of plate tectonics. They were introduced in the somewhat abstruse text of his book $\mathrm{La}$ Tectonique de l'Asie (Schaer, 2010) and they were never to be made easier to understand or widely propagated by the author himself. A few students and a few young colleagues of his were to make an effort at broadcasting those ideas. Given the fact that Argand did not offer them any support, their efforts were to prove rather unsuccessful, all the more so since as time went by, the messengers were attracted to other scientific fields of investigation, often far removed from geology. In Neuchatel itself, however, the continued expression of his ideas did help to keep alive a feeling of admiration for the revered Master that was to last for several decades. It was in this way that also a positive view on the idea of continental drift endured. The critical statements of Wegmann, Argand's successor, concerning certain aspects of the theory, were mostly misunderstood or not clearly grasped. They had no influence on the way continental drift came to be accepted in the town that had been testimony of the strength of its impetus.

In Switzerland, way beyond the 1940s, there was otherwise a kind of mental block when it came to the ideas that formed the intellectual legacy of people like Wegener, Argand or Staub. A few scientists were probably aware of the fact that in order to go beyond the views expressed by the exuberant imagination of those scientists, it would have been necessary to dispose of new data of a global nature. However, at that time, Alpine research found itself involved in a structural approach that was turning more and more to local issues and was getting more and more specialised. It was very often cut off from the interesting developments that had recently taken place in sedimentology as it was practised in the marine environment 
(Trümpy, 2003). Even the interesting propositions that Staub and his students had put forward concerning the association of ophiolitic masses with tectonic units were quickly shed because they diverged too far from current views in ocean and Alpine research. Once again, generally accepted views prevailed over new evidence coming from geological fieldwork, even though the analysis was trying to be subtle and objective.

In contrast to continental drift, which was based upon a new interpretation of existing data, coming from a variety of disciplines, plate tectonics drew upon facts and arguments that were the product of recent intensive research carried out by geophysicists and oceanographers in marine domains that, until then, had remained almost unknown. The abundance and quality of this wealth of information proved so fruitful that the old approaches seemed devoid of interest, whether the facts they provided or the ideas they provoked. Continental geology was practically ignored, except for the narrow zones of seismic activity, which were mapped out on a global scale, also those by geophysicists. Right at its inception, therefore, the new theory had a remarkable internal coherence, but at the same time it had become highly specialised and depended heavily on major geophysical and oceanographic resources, which many detractors would see as major flaw. In the post-war period, due to the climate of international tensions (the Cold War), oceanographic research became a high priority and was carried out on a global scale. It was the magnitude of the task and the strategic goals that people were trying to reach that gave the whole project such gigantic proportions and made it the exclusive preserve of the superpowers. This situation led to a certain isolation of the researchers taking part in the enterprise, a feeling of seclusion which was further reinforced because most of the data gathered was initially kept secret. The fact that geophysics had reached such a dominant position and the fact it required such mammoth investment led, even in the USA, to a situation of monopoly, held, for instance, by exclusive institutions like the Lamont Geological Observatory and the Script Institution of Oceanography, and a few other research centres-led by people with strong personalities such as Hess in Princeton, Ewing at Lamont, and Bullard in Cambridge. Le Pichon (1984) noted that for these reasons "the French were absent from the field of oceanography" and did not play a very active role in the field of geophysics, either. The same could be said of other nations of continental Europe, including Switzerland, and as a result they found themselves excluded from the debate that brought about the emergence of the "new global tectonics", as it was called at first.

Within the space of barely more than twenty years, making full use of all the means that were put at their disposal, the scientists who were exploring the oceanic domain managed to provide a clear image of its inner structure and evolution. This in turn made it much easier to set out the theory of plate tectonics, which would encompass the dynamics of the whole of the Earth. It did not solve all problems, but it radically modified the range of priorities, particularly when it came to research fields. The continental areas lost their privileged status: they were dragged along in a passive way by the lithosphere and were no longer the key element in the Earth dynamics. Faced with this new situation, the community of Alpine geologists showed, in general, extreme reticence, and most geologists with field experience had the same reaction. There were various causes for this resistance. To all the reservations that had been expressed earlier to Wegener's theory, which superficially seemed to be a forerunner of plate tectonics, was added the small amount of credit they granted to geophysics and oceanography, especially that the data the latter provided were always open to diverse interpretations. At best, those communities could go as far as accepting the great clarity of the structures found in the ocean, but they were of the opinion that the integration of these data with those of continental geology was problematic. This was all the more so because the complex structures found on the continents bore no resemblance to the apparent simplicity of the ocean floors. For some people, the loss of their private research kingdoms and of the potential glory attached to them may also explain their resistance to the introduction of the new theory. Although the great overthrusts that had been clearly identified by the end of the nineteenth century in the Alps and other mountain chains could not be accounted for by the supposed contraction of the Earth, most Alpine geologists were extremely critical of the hypothesis of continental drift, in spite of Argand's influence, and, later, of plate tectonics. In the latter case, the reaction in Switzerland was partly influenced by the fact that there was very little interest in those circles for geophysics. A certain inertia can be discerned, a certain clinging to traditional ideas, an excessive conservatism. The resounding successes of Alpine geology in the past seems to have played an important role, fostering a refusal of geologists to commit themselves to the new avenues of research. There was, at the time, an attitude which led to narrower and narrower specialisation, to a focus on the finer and finer details of Alpine structure, and to a manifest lack of interest in the revolution which was taking place and in the contributions of closely related geoscientific disciplines. Nevertheless, the winds of change were blowing, and important steps were made by people who kept a broad-minded attitude and could see beyond the national borders and the confines of geological disciplines. In Switzerland and other Alpine countries, geologists and geophysicists eventually found each other, large-scale projects were carried through, and 
the significance of the detailed picture of the Alpine orogeny which had been painstakingly built up over the preceding decades, between the two revolutions, as a testing ground and as a window into the Earth, became better recognised.

Acknowledgments Of the many colleagues and friends who gave me their generous support during the preparation of this contribution, I would like to mention and thank especially Nathalie Ray, D. Bernoulli, J. Gaudant, the late M. Lemoine, C. Sengör and the late R. Trümpy. My special thanks go to Gerard Daniel who, without being a geologist, made an excellent job of translating my French text into English. A.G. Milnes deserves my full gratitude for his long and lasting help, his critical review and his valuable suggestions for improving the text.

\section{Appendix: Contents of Part 1 and Part 2}

Swiss and Alpine geologists between two tectonic revolutions

by Jean-Paul Schaer

Part 1: from the discovery of nappes to the hypothesis of continental drift

(published in Swiss Journal of Geosciences, Volume 103, Number 3)

Introduction

Ideas on mountain building at the beginning of the twentieth century

Alpine geologists' interpretation of mountain formation

Die Entstehung der Continente und Ozeane (Wegener, 1915)

Wegener's propositions and the first reactions to them

The developing debate

The reaction in Switzerland

La Tectonique de l'Asie (Argand, 1924) and Carte Tectonique de l'Eurasie (Argand, 1928)

Argand and ophiolites

Argand and geophysics

After La Tectonique de l'Asie

Part 2: from drifting continents towards plate tectonics

(published in Swiss Journal of Geosciences, Volume 104, Number 4-this issue)

1. Introduction

2. Argand's heritage

2.1 Gustav Juvet (1896-1936)

2.2 Rolin Wavre (1896-1949)

2.3 John Leuba (1884-1952)

\subsection{Other carriers of Argand's ideas}

3. Diverse opinions between the World Wars and beyond

3.1 Neuchâtel in the post-Argand period

3.2 Other Swiss reactions

3.3 Ampferer on continental mobility and drift mechanisms

3.4 Decline in the influence of Wegener's ideas

3.5 The "Atlantis" conference, Frankfurt 1939

3.6 Dichotomy of approaches: Wegener, Argand and their heirs

4. The advent of plate tectonics in the Alps

4.1 View from the Alpine sidelines

4.2 Late development of geophysics in Switzerland

4.3 The slow awakening

4.4 The power and limits of imagination-words and images

5. Overall considerations and conclusions.

\section{References}

Ampferer, O. (1906). Uber das Bewegungsbild von Faltengebirgen. Jahrbuch der geologischen Reichesanstalt, 56, 539-622.

Ampferer, O. (1924a). Beiträge zur Auflösung der Mechanik der Alpen. 1. Fortsetzung. Jahrbuch der geologischen Bundes Antschalt, 74, 35-73.

Ampferer, O. (1924b). Uber die tektonik der Alpen. Naturwissenschaften, 12, 1007-1014.

Ampferer, O. (1925). Uber Kontinentverschiebungen. Naturwissenschaften, 13, 669-674.

Ampferer, O. (1941). Gedanken über das Bewegunsbild des atlantischen Raumes. Sitzungsberischte Akademie der Wissenschaften. in Wien, Mathematisch. naturwissenschaften Klasse, 149, 19-35.

Amstutz, A. (1951). Sur l'évolution des structures alpines. Archives Sciences physiques et naturelles, Genève, 4, 323-329.

Argand, E. (1911). Les nappes de recouvrement des Alpes occidentales et les territoires environnants. Essai de carte structurale 1: 500'000. Matériaux Carte Géologique de la Suisse, n.s. 27, carte spéciale no. 64.

Argand, E. (1916). Sur l'arc des Alpes occidentales. Eclogae Geologicae Helvetiae, 14, 145-191.

Argand, E. (1920). Plissements précurseur et plissements tardifs des chaînes de montagnes. Actes Société helvétique, Sciences Naturelles, Neuchâtel, 1920, 13-39.

Argand, E. (1924). La tectonique de l'Asie. Congrès géologique international, XIII e Session, Bruxelles, Proceedings (pp. 171-372).

Argand, E. (1928). Procès-verbal de la séance du 3 novembre 1916 de la Société des Sciences naturelles de Neuchâtel: Vues modernes sur l'origine des continents et des Océans. Bulletin de la Société Neuchâteloise des Sciences Naturelles, 42, 117.

Argand, E. (1934). La zone pennique. Guide géologique de la Suisse, III (pp. 149-189). Basel: Wepf.

Bernauer, F. (1939). Island und die Frage der Kontinentalverschiebungen. Geologische Rundschau, 30, 357-358. 
Berner R. (1925). Sur la grandeur de la force qui tendrait à rapprocher un continent de l'équateur. Dissertation, University of Geneva.

Bernoulli, D. (1972). North Atlantic and Mediterranean Mesozoic facies: a comparison. In C. D. Hollister, J. I. Ewing, et al. (Eds.), Initial reports of the deep sea drilling project 11 (pp. 801-871). Washington DC: US Government Printing Office.

Bernoulli, D. (2001). Mesozoic-tertiary carbonate platforms, slopes and basins of the external Apennines and Sicily. In G. B. Vai \& P. Martini (Eds.), Anatomy of a Orogen: the Apennines and adjacent Mediterranean basins (pp. 307-325). Amsterdam: Kluwer Academic Publishers.

Bernoulli, D., \& Jenkyns, H. C. (1974). Alpine, Mediterranean and central Atlantic Mesozoic facies in relation to the early evolution of the Tethys. In R. H. Dott Jr., \& R. H. Shaver (Eds.), Modern and ancient geosynclinal sedimentation (pp. 129-160). SEPM Special Publication, 19.

Bernoulli B., \& Jenkyns, H. C. (2009). Ancient oceans and continental margins of the Alpine-Mediterranean Tethys: deciphering clues from Mesozoic pelagic sediments and ophiolites. Sedimentology, 56, 149-190.

Blundell, D., Freeman, R., \& Müller, S. (Eds.) (1992). A continent revealed. The European geotraverse (p. 275). Cambridge, UK: Cambridge University Press.

Bull, A. J. (1921). A hypothesis of mountain building. Geological Magazine, 58, 364-367.

Carey, S. W. (Ed.) (1958). Continental drift. A symposium. Hobart: University of Tasmania, Department of Geology.

Carey, S. W. (1976). The expanding earth. New York: Elsevier.

Carozzi, A. V. (1985). The reaction in continental Europe to Wegener's theory of continental drift. Earth Sciences History, 4, 122-137.

Collet, L. W. (1935). The structure of the Alps. Second Edition (304 pp.). London: Ed. Arnold.

Daly, R. A. (1933). The depths of the earth. Bulletin Geological Society of America, 44, 243-264.

Daly, R. A. (1942). The floor of the ocean (p. 177). University of North Carolina Press: Chapel Hill.

de Sitter, L. U. (1956). Structural geology (2nd ed ed.). New York: McGraw-Hill.

Dewey, J. F., Pitman, W. C., Ryan, W. B. F., \& Bonin, J. (1973). Plate tectonics and the evolution of Alpine system. Bulletin Geological Society of America, 84, 3137-3180.

Dewey, J. F. (2003). Plate tectonics and geology, 1965 to today. In N. Oreskes (Ed.), Plate tectonics. An insider's history of the modern theory of the earth (pp. 227-242). Boulder: Westview Press.

Dubois G., \& Portmann J. P. (1955). Histoire géologique de la Suisse, servant de commentaire sur les beauté du pays et de ses montagnes, de leur beauté de nature (p. 143). Neuchâtel: Gymnase cantonal.

du Toit, A. L. (1929). A geological comparison of South America and South Africa. Washington DC: Publication of the Carnegie Institution, No. 381

du Toit, A. L. (1937). Our wandering continents. Edinburgh: Oliver and Boyd.

Ewing, M., \& Press, F. (1955). Geophysical contrast between continents and oceans. Geological Society of America, Special Paper, 62.

Fehr, H. (1950). Rolin Wavre, 1896-1949. Actes Société helvétique, Sciences Naturelles, Neuchâtel, 1950, 420-428.

Field, R. (Ed.) (1938). Geophysical exploration of the ocean bottom. In Proceedings of the American Philosophical Society (p 79).

Fisher, O. (1889). Physics of the Earth's Crust. Second Edition (291 pp.). London: MacMillan.

Gagnebin, E. (1922). La dérive des continents selon la théorie d'Alfred Wegener. Revue générale des Sciences, 33, 293-304.

Gagnebin, E. (1946). Histoire de la Terre et des Etres Vivants (p. 165). Lausanne: Guilde du Livre.
Gassmann, F. (1950). Recent geophysical research work. Bulletin Vereiningung schweizerischen Petroleum-Geologen und Ingenieure, 17, 5-14.

Gassmann, F., \& Prosen, D. (1946). Graphische Bestimmung der Wirkung gegebener drei dimensionaler Massen auf die Schwereintensität. Eclogae Geologicae Helvetiae, 39, 199-210.

Gaudant, J. (1995). La réception de l'idée de la dérive des continents en France et en Suisse romande: les enseignements d'une enquête. Mémoire de la Société géologique de France, 168, 129-138.

Goguel, J. (1952). Traité de Tectonique. Paris: Masson.

Goguel, J. (1965). Traité de Tectonique, Seconde édition. Paris: Masson.

Goguel, J. (1959). La Terre. Paris: Encyclopédie de la Pléiade.

Gutenberg, B. (1951). Crustal layers of the continents and oceans. Bulletin Geological Society of America, 62, 427-440.

Gutenberg, B., \& Richter, C. F. (1939). Structure of the crust. Continents and oceans. In B. Gutenberg (Ed.), Internal constitution of the earth, physics of the earth VII. New York: McGrawHill.

Gutenberg, B., \& Richter, C. F. (1954). Seismicity of the earth. Princeton: Princeton University Press.

Guyot, E. (1934a). Contrôle géodésique de la théorie des translations de Wegener. Annales Guébhard-Séverine, 10, 404-410.

Guyot, E. (1934b). L'emploi d'une projection cylindrique oblique pour l'étude de la dérive des continents. Bulletin Société neuchâteloise Sciences naturelles, 68, 105-111.

Guyot, E. (1935). Les théories des translations continentales et l'astronomie. Annales Guébhard-Séverine, 11, 57-73.

Heck, N. H. (1938). The role of earthquakes and the seismic method in submarine geology. Proceedings of the American Philosophical Society, 79, 97-108.

Heim, A. (1918). Das Gewicht der Berge. Jahrbuch des Schweizer Alpenclub, 53, 179-201.

Heim, A. (1919-1922). Geologie der Schweiz (Vol. 1, p. 704, Vol. 2, p. 1018). Leipzig: Tauchnitz.

Hess, H. H. (1962). History of the ocean basins. In Petrologic Studies: A volume to honor A.F. Buddington. Denver: Geological Society of America.

Holmes, A. (1928a). Radioactivity and continental drift. Geological Magazine, 65, 236-238.

Holmes, A. (1928b). Review of W.A.J.M. van Waterschoot van der Gracht, ed., theory of continental drift. Nature 122, 431-433.

Holmes, A. (1929). Radioactivity and earth movements. Transactions of the Geological Society Glasgow, 18, 559-606.

Holmes, A. (1930). Radioaktivität und Geologie. Verhandlungen der Naturforschenden Gesellschaft, Basel, 41, 136-185.

Holmes, A. (1944). Principles of physical geology. New York: Roland Press.

Hsü, K. (1971). Origin of the Alps and Western Mediterranean. Nature, 233, 44-48.

Isacks, B., Oliver, J., \& Sykes, L. R. (1968). Seismicity and the new global tectonics. Journal of Geophysical Research, 73, $5855-5899$.

Jeffreys, A. (1926). The Earth's thermal history and some related problems. Geological Magazine, 63, 516-525.

Juvet, G. (1921). Introduction aux théories de M. Einstein en vue de leur application à l'astronomie (p. 25). Neuchâtel: André Seiler.

Juvet, G. (1925). La dérive des continents et la formation des montagnes. La Revue Universelle, 23, 494-504.

King Lester, C. (1962). The morphology of the earth (p. 711). Edinburgh and London: Oliver and Boyd.

Laubscher, H. P. (1969). Mountain building. Tectonophysics, 75, 551-563.

Laubscher, H. P. (1970). Bewegung und Wärme in der alpinen Orogenese. Schweizerische Mineralogische und Petrographische Mitteilungen, 50, 565-569. 
Laubscher, H. P. (1971a). Das Alpen-Dinariden-Problem und die Palinspastik des südlichen Tethys. Geolgische Rundschau, 60, 829-833.

Laubscher, H. P. (1971b). The large-scale kinematics of the western Alps and the northern Apennines and its palinspastic implication. American Journal of Science, 271, 193-226.

Le Grand, H. E. (1988). Drifting continents and shifting theories. Cambridge: Cambridge University Press.

Lemoine, M. (2004). De Wegener à la tectonique des plaques: sept fois sept ans de réflexion. Travaux du Comité français d'histoire de la Géologie.3è série, 18, 103-131.

Le Pichon, X. (1984). La naissance de la tectonique des plaques. $\mathrm{La}$ Recherche, 153, 414-422.

Leuba, J. (1925). Introduction à la Géologie (p. 216). Paris: Collection Armand Colin.

Marvin, U. B. (1985). The British reception of Alfred Wegener's continental drift hypothesis. Earth Sciences History, 4, 138-159.

Menard, H. W. (1986). The ocean of truth. Princeton: Princeton University Press.

Mercier, A. (1933). Contribution à la théorie des dérives continentales. Archives Sciences physiques et naturelles, Genève, $5^{e}$ période, 15, 225-243; 324-342.

Meyer de Stadelhofen, C. (1967/68). Professeur Dr. Edouard Poldini. Bulletin Association suisse Géologues. et Ingénieurs du pétrole, $34,53$.

Molengraaff, G. A. F. (1928). Wegener's continental drift. In W. A. J. M. van Watterschoot van der Gracht (Ed.), The theory of continental drift. A symposium (pp. 90-92). London: American Association of Petroleum Geologists.

Milnes, A. G. (2009). De la nécessité de rêver. Impressions from the Symposium in honour of Rudolf Trümpy held at the ETH Zürich on 2 October 2009: Alpengeologie im 21. Jahrhundert. Swiss Journal of Geosciences, 102, 383-389.

Niggli, E. (1946). Uber den Zusammenhang zwischen der positiven Schweranomalie am Südfuss der Westalpen und der Gesteinszone von Ivrea. Eclogae Geologicae Helvetiae, 39, 211-220.

Oliver, J. (2003). Earthquake seismology in the plate tectonics revolution. In N. Oreskes (Ed.), Plate tectonics. An insider's history of the modern theory of the earth (pp. 155-166). Boulder: Westview Press.

Oreskes, N. (1999). The rejection of continental drift. Oxford: Oxford University Press.

Oreskes, N. (2003). Plate tectonics. An insider's history of the modern theory of the earth. Boulder: Westview Press.

Pavoni, N. (1965). Zur Geschichte der Erdbebenforschung in der Schweiz. Jahresbericht des Schweiz Erdbebendienstes, 1962, $37-43$.

Pavoni, N. (1990). Fritz Gassmann. Bulletin der Vereiningung schweizerischen Petroleum-Geoleologen und Ingenieure, 57, 75-76.

Paréjas, E. (1957). Léon-William Collet (1880-1957). Actes Société Helvétique des Sciences Naturelles, Neuchâtel, 137, 306-315.

Pfiffner O. A., Lehner, P. Heitzmann, P. Muller, S., \& Steck, A. (1997). Deep structure of the Swiss Alps: results from NRP 20 (p. 380). Basel: Birkhäuser Verlag.

Ray, N. (2004). La théorie de la dérive des continents d'Alfred Wegener vue par deux géologues alpins contemporains : Emile Argand et Pierre Termier. Diplôme d'Etudes Approfondies d'Epistémologie et Histoire des Sciences et Techniques, Université Paris VII (unpublished Diploma thesis).

Ray, N. (2005). Pierre Termier (1859-1930) et la mobilité continentale. Travaux du Comité français d'Histoire de la Géologie, $3 e ̀$ série, 19, 51-77.

Reichel, M. (1924). La Genèse des Continents et des Océans. Traduction de l'oeuvre de A. Wegener: Die Entstehung der Kontinent und Ozeane. Paris: Blanchard (Collection: Monographies Scientifiques Etrangères).
Renaud, A. (1963). Prof. Dr Paul-Louis Mercanton. Actes Société Hélvetique Sciences Naturelles, 1963, 231-241.

Rittmann, A. (1939). Bemerkung zum "Atlantis"-Tagung in Frankfurt im Jahre 1939. Geologische Rundschau, 30, 284.

Roure, F., Heitzmann, P., \& Polito, R. (Eds.) (1990). Deep structure of the Alps. Mém. Soc. géol. Fr., Paris 156; Mém. Soc. géol. suisse, Zürich, 1; Vol. spec. Soc Geol. It., Roma.

Schaer, J.-P. (1991). Emile Argand 1879-1940: life and portrait of an inspired geologist. Eclogae Geologicae Helvetiae, 84, 511-534.

Schaer, J.-P. (2002). La faculté des Sciences. In L'Histoire de l'Université de Neuchâtel (p. 476). Neuchâtel: Université de Neuchâtel, Hauterive: Editions Gilles Attinger.

Schaer, J.-P. (2003). La dérive des continents, son accueil à Neuchâtel et parmi les géologues alpins. Travaux du Comité français d'Histoire de la Géologie (3), 17, 159-173.

Schaer, J.-P. (2005). Gustave Juvet, 1896-1936. In M. Schulp (Ed.), Biographie Neuchâteloise (pp. 169-174). Hauterive: Editions Gilles Attinger.

Schaer, J.-P. (2010). Swiss and Alpine geologists between two tectonic revolutions. Part 1: from the discovery of nappes to the hypothesis of continental drift. Swiss Journal of Geosciences, 103, 503-522.

Schaer, J.-P., \& Rodgers, J. (Eds.). (1987). The anatomy of mountain ranges. Princeton: Princeton University Press.

Schardt, H. (1928). Zur Kritik der Wegenerschen Theorie der Kontinentenverschiebung. Vierteljahreschrift der Naturforschende Gesellschaft, Zürich, 73, XIV-XV.

Sclater, J. (2003). Heat flow under the oceans. In N. Oreskes (Ed.), Plate tectonics. An insider's history of the modern theory of the earth (pp. 128-147). Boulder: Westview Press.

Schmid, S. M. (2009). Rudolf Trümpy (1921-2009); scientific achievements of an outstanding personality with a life-long commitment to teaching and research in geology. Swiss Journal of Geosciences, 102, 375-382.

Sengör, A. M. C. (1990). Plate tectonics and orogenic research after 25 years: a Tethyan perspective. Earth Sciences Reviews, 27, $1-201$.

Sengör, A. M. C. (1996). Eine Ergänzung der Carlé'schen Liste der Veröffentlichungen von Hans Stille und einzige Schlüsse: Ein Beitrag zur Geschischte und Philosophie der tektonsichen Forschung. Zentralblatt für Geologie und Paläontologie. Teil I., 1994, 1051-1106.

Sengör, A. M. C. (1998). Die Tethys: vor Hundert Jahren und heute. Mitteilung der Osterreichischen Geologische Gesellschaft, 98.

Sengör, A. M. C. (2003a). The repeated rediscovery of mélanges and its implications for the possibility and the role of objective evidence in the scientific enterprise. Geological Society of America, Special Paper, 373, 383-445.

Sengör, A. M. C. (2003b). The large-wavelength deformations of the lithosphere. Geological Society of America, Memoir 196 (p. 362).

Sengör, A. M. C., \& Okurogullari, A. H. (1991). The rôle of accretionary wedges in the growth of continents: Asiatic examples from Argand to plate tectonics. Eclogae Geologicae Helvetiae, 84, 535-597.

Staub, R. (1924). Bau der Alpen. Beiträge zur Geologische Karte des Schweiz NF, 52, 1-272.

Suess, E. (1921). La Face de la Terre (translation of « Das Antlitz der Erde » by E. de Margerie) (258 pp.). Paris: Armand Colin.

Termier, P. (1923). La déformation de la surface terrestre au cours des âges. Conférence à la Société industrielle de Mulhouse, avril 1923 , p. 26.

Termier, P. (1926). La dérive des continents. In P. Termier (Ed.), $L a$ Joie de Connaitre (pp. 161-200). Paris: Nouvelle Librairie Nationale.

Termier, P. (1929). Quelques récents progrès de la géologie. In P. Termier (Ed.), La Vocation de Savant (pp. 161-196). 
Trümpy, R. (1960). Paleotectonic evolution of the Central and Western Alps. Bulletin of Geological Society of America, 71, 843-906.

Trümpy, R. (1991). In the footsteps of Emile Argand: Rudolf Staub's Bau der Alpen (1924) and Bewegunsmechanismus der Erde (1928). Eclogae Geologicae Helvetiae, 84, 661-670.

Trümpy, R. (2001). Why plate tectonics was not invented in the Alps. Geologische Rundschau, 90, 477-483.

Trümpy, R. (2003). Trying to understand Alpine sediments-before 1950. Earth Science Reviews, 61, 19-42.

van der Watterschoot van der Gracht, W. A. J. M. (Ed.) (1928). The theory of continental drift. A symposium. London: American Association of Petroleum Geologists.

van der Watterschoot van der Gracht, W. A. J. M. (1939). Bemerkungen zur Atlantistagung. Geologische Rundschau, 30, 297-302.

von Klebelsberg, R. (1947). Otto Ampferers geologisches Lebenswerk. Jahrbuch der Geologischen Bundesanstalt, 92, 93-116.

Wavre, R. (1925). Sur la force qui tendrait à rapprocher un continent de l'équateur. Genève: Archives Sciences physiques et naturelles.

Wavre, R. (1932). Figures Planétaires et Géodésie. Paris: GauthierVillars.
Wegmann, E. (1943a). Zur Feststellung von Landverschiebung in der Arktis. Geologische Rundschau, 34, 236-242.

Wegmann, E. (1943b). Sur un contrôle géologique de la dérive des continents. Bulletin Société neuchâteloise des Sciences naturelles, 68, 97-104.

Wegmann, E. (1948). Geological tests of the hypothesis of a continental drift in the Artic Regions. Meddelelser om Grönland, $144,1-48$.

Wegmann, E. (1950). L'exploration des espaces intercontinentaux. Bulletin Sociéténeuchâteloise des Sciences naturelles, 73, 81-100.

Wegener, A. L. (1912a). Die Entstehung der Kontinente. Petermanns Geographische Mitteilungen, 58, 185-195, 253-256, 305-309.

Wegener, A. L. (1912b). Die Entstehung der Kontinente. Geologische Rundschau, 3, 276-292.

Wegener, A. L. (1915). Die Entstehung der Kontinente und Ozeane (p. 94). Braunschweig: F. Viewig.

Wegener, A. L. (1924). La Genèse des Continents et des Océans (p 166). Paris: Albert Blanchard.

Wegener, A. L. (1936). Die Entstehung der Kontinente und Ozeane (5th, unchanged, Ed., p. 242). Br

White, D. A., Roeder D. H., Nelson, T. H., Crowell J. C. (1970). Subduction. Bulletin Geological Society of America, 81, $3431-3432$ 